J. M. Austin and J. E. Shepherd. "Detonation in Hydrocarbon Fuel Blends" Combustion and Flame, Vol. 132(1-2), 73-90, 2003.

\title{
Detonations in Hydrocarbon Fuel Blends
}

\author{
J.M. Austin and J.E. Shepherd \\ Graduate Aeronautical Laboratories, \\ California Institute of Technology \\ Pasadena, California 91125 \\ accepted to Combust. Flame, Jan. 2002 \\ revised June 2002
}

Full-length article

Corresponding Author:

Prof. J.E. Shepherd

Mail Stop 105-50

California Institute of Technology

1200 E California Blvd.

Pasadena, California 91125

ph: (626) 3953283

fax: (626) 4492677

jeshep@galcit.caltech.edu 


\section{Abstract}

A study of detonations in high-molecular weight hydrocarbon fuels of interest to pulse detonation engine applications was performed in a $280 \mathrm{~mm}$ diameter, $7.3 \mathrm{~m}$ long facility. Detonation pressure, wave speed, and cell width measurements were made in JP-10 mixtures and in mixtures representative of the decomposition products of JP-10.

Experiments were performed in vapor-phase JP-10 mixtures at $353 \mathrm{~K}$ over a range of equivalence ratios $(0.7 \leq \phi \leq 1.3)$, nitrogen dilutions (fuel-oxygen to fuel-air), and initial pressures $(20-130 \mathrm{kPa})$. The cell widths of the JP-10 mixtures are found to be similar to those of propane mixtures. A fuel blend representative of thermally decomposed JP-10 was studied at $295 \mathrm{~K}$. This blend consisted of hydrogen, carbon monoxide, methane, acetylene, ethylene, and hexane with varying fractions of oxygen and nitrogen. The measured cell width of the fuel blend-air mixture is about half that of JP-10-air. The addition of components of the fuel blend (acetylene, ethylene, and methane) to JP-10 in air at $353 \mathrm{~K}$ was characterized.

Nitrogen diluted mixtures of stoichiometric hexane-oxygen were studied and the cell widths for hexane-air and JP-10-air are found to be comparable. The addition of lower molecular weight fuels (hydrogen, acetylene, ethylene, 
and carbon monoxide) to hexane-air was investigated. The measured cell width decreases, indicating increased sensitivity to detonation, with increasing fraction of hydrogen, acetylene, and ethylene, in order of effectiveness. The addition of a small fraction of carbon monoxide produces a small decrease in the cell width, but addition of more than about $75 \%$ (by fuel mass) carbon monoxide results in a significant increase in cell width.

Carbon monoxide is a principal intermediate product of hydrocarbon combustion yet there are relatively little cell width data available. Cell width measurements were made in carbon monoxide-air mixtures with the addition of hydrogen or hydrocarbons (acetylene, ethylene, and hexane). A linear relationship is found between the cell width and the reaction zone length when it is defined as the location of the peak in hydroxyl mole fraction. 


\section{Introduction}

Liquid hydrocarbons are the fuel of choice for aviation propulsion systems, including the pulse detonation engine (PDE) concept. Much of the published PDE research carried out up to the present time has used gaseous fuels, $\mathrm{C}_{1^{-}}$ $\mathrm{C}_{3}$ hydrocarbons, due to the difficulty of creating uniform fuel-air mixtures with liquid hydrocarbon fuels and initiating detonation in these mixtures. The present investigation is part of a larger study that considers how liquid fuels can best be utilized in PDEs.

A liquid hydrocarbon fuel can be partially decomposed into smaller molecules $\left(\mathrm{C}_{1}\right.$ to $\left.\mathrm{C}_{5}\right)$ by fuel-rich combustion or by thermal cracking. Fuel-rich catalytic combustion uses the presence of a catalyst to achieve combustion beyond the rich combustion limit, producing reactive molecules, high temperatures and relatively little soot. Catalytic combustion of JP-10 was studied by Brabbs and Merritt [1] in an effort to find a storable liquid fuel which had an ignition delay time that was less than the residence time in the combustion chamber of a hypersonic vehicle. The majority of the combustion products were low-molecular weight hydrocarbons that are also more susceptible to detonation, making this process an attractive possibility for PDE fuels. Smaller molecular weight products may act as "sensitizers" to the parent fuel, re- 
ducing the critical energy required to initiate a detonation compared to the parent fuel. This study compares the characteristic detonation cell widths of JP-10 with fuel blends that are representative of the products of liquid fuel decomposition.

\section{Experimental details}

Experiments were performed in the gaseous detonation tube (GDT) ([2], [3]) shown in Fig.1. The stainless steel detonation tube is $7.3 \mathrm{~m}$ long and has an internal diameter of $280 \mathrm{~mm}$. Before each shot, an aluminum sheet or "foil" (0.61 m by $0.91 \mathrm{~m}$ by $0.5 \mathrm{~mm}$ ) is rolled, riveted to a steel ring, and covered in a light layer of soot. For experiments at elevated temperatures, the aluminum foils are first coated with a thin layer of Dow-Corning DC200 Silicon (viscosity $20 \mathrm{cs}$ ) to assist in retaining the soot. The foil is inserted into the downstream end of the tube and anchored in place. The entire tube is evacuated to about $10 \mathrm{~Pa}$ and then filled by the method of partial pressures. Pressure in the tube is measured by an electronic Heise 901a gauge which is accurate to $\pm 0.17 \mathrm{kPa}$. Liquid fuels may be injected into the evacuated tube through a septum. The partial pressure of hexane (vapor pressure of 
$20 \mathrm{kPa}$ at $298 \mathrm{~K}$ ) is low enough to ensure that the fuel had vaporized at room temperature. However, for the experiments involving JP-10, the facility is heated to between 353 and $373 \mathrm{~K}$. Comparison with JP-10 vapor pressure data (Fig. 2) shows the temperature is sufficient to ensure the JP-10 is vaporized. The circulation lines (lines which are used to circulate the gas prior to the experiment to ensure the mixture is homogeneous) are maintained at a higher temperature than the detonation tube to ensure no fuel condenses in the lines. The temperature is monitored at 19 locations throughout the facility. For liquid fuels, the fuel is injected in small increments to ensure the rise in partial pressure is linearly proportional to the injected volume. Since the exact volume of the tube is unknown, this linear behavior is taken to show that, to within the accuracy of the gauge, no fuel is condensing.

Ignition is by an exploding wire which is created by discharging a $2 \mu \mathrm{F}$ capacitor (initially charged to $9 \mathrm{kV}$ ) through a copper wire. The exploding wire initiates a slug of oxygen-acetylene driver gas that is injected into the tube in the vicinity of the wire just prior to ignition. The initiation system is described in greater detail in Akbar [2]. The equivalent energy of the driver gas is calculated from the blast wave in air by the procedure described in Thibault et al. [4], and found to be 70-100 kJ, with the $100 \mathrm{~kJ}$ driver used 
in $\mathrm{CO}$ and $\mathrm{JP}-10$ experiments.

Three PCB pressure transducers, mounted along the tube, record the detonation pressure and time-of-arrival of the wave which is used to calculate the wave speed. The chemical equilibrium program STANJAN [5] is used to calculate the Chapman-Jouguet (CJ) wave speed, pressure, and temperature. The wave speed obtained from the pressure transducers is checked against the calculated value and is typically within $\pm 1 \%$. In the case of the leastsensitive mixtures studied (cell width $\approx 100 \mathrm{~mm}$ ) the velocity deficit is within $\pm 1.5 \%$ of the CJ velocity between the second and third pressure transducers. So in all cases, the length of the tube is sufficient for cell measurements to be unaffected by the initiation transient. Two sets of pressure traces are shown in Fig. 3. On the left, Fig. 3a, the mixture has a detonation cell width of $100.3 \mathrm{~mm}$ and larger scale oscillations in pressure are evident in comparison to a pressure history from a mixture with much smaller cell width (Fig. 3b). As the detonation propagates over the sooted foil, a cellular pattern is scoured in the soot. The cellular pattern is associated with the instability of the detonation front. The cells are a measure of the spacing of the transverse waves which perturb the front. The average width of the transverse wave spacing recorded on a sooted foil will be referred to in this paper as the 
detonation cell width. There can be a spectrum of cell widths recorded for a particular mixture due to the inherent irregularity of the cells. About 10 measurements are made on each foil from which a minimum, a maximum, and an average cell width are recorded. To give an indication of the range of cell widths recorded for each experiment, the minimum and maximum cell width are presented in the form of "error bars" about the average value. Cell width measurements are subject to variation from observer to observer. These can be on the order of $\pm 50 \%$ [6]. To minimize this, all present data were measured by one observer.

The measured cell width is independent of the facility dimensions only if the size of the facility is sufficient to accomodate several cells. The diameter of the tube used in the current study is $280 \mathrm{~mm}$. Therefore cell widths of $100 \mathrm{~mm}$ or above are reported only to give an indication of the observed trend, and should not be taken as absolute values.

During the course of this study, the facility was modified to accommodate reflected pressures of up to $10 \mathrm{MPa}$; however, some data were obtained before this modification. These experiments were limited to mixtures producing reflected pressures of $5 \mathrm{MPa}$, the original design limit of the facility. In any case where the reflected pressure of the mixture would exceed the facility 
design limit, the test was performed at the highest initial pressure possible, then the cell widths for $100 \mathrm{kPa}$ initial pressure were estimated by assuming the cell width varies in inverse proportion to the initial pressure. These data are presented as "extrapolated".

\section{Cell width measurements}

\section{Vapor-phase JP-10 mixtures}

Cell width measurements were made in mixtures with vapor-phase JP-10 at 353-373 K. The detonation wave velocity was recorded for comparison with the calculated CJ velocity. A sample comparison is shown in Fig. 4. The average cell size of stoichiometric JP-10-air is found to be $60.4 \mathrm{~mm}$, with minimum and maximum cell widths of 39 and $84 \mathrm{~mm}$ recorded. Cell widths in JP-10-air mixtures with varying equivalence ratio are reported in Fig. 5. The minimum and maximum cell widths measured are indicated by the horizontal bars. The cell widths in JP-10 are comparable to data published in Akbar et al. [7] and are shown to be on the order of previous measurements of $\mathrm{C}_{3} \mathrm{H}_{8}$-air cell widths, suggesting that propane may be a useful surrogate fuel for preliminary pulse detonation engine studies. 
The effect of varying initial pressure is shown in Fig. 6 in stoichiometric JP-10-air and JP-10- $\mathrm{O}_{2}$ mixtures. In both cases, the cell width decreases with increasing pressure.

Fig. 7 shows cell widths in JP-10- $\mathrm{O}_{2}$ with varying $\mathrm{N}_{2}$ dilution, from no dilution $(\beta=0)$ up to equivalent air $(\beta=3.76)$, where $\beta$ is the molar ratio of $\mathrm{N}_{2}$ to $\mathrm{O}_{2}$ concentration. The ratio of the cell widths of JP-10-air to JP-10oxygen is around 60 . The critical initiation energy has been shown to be proportional to the cube of the cell width for a spherical geometry $([8],[9])$. For a planar initiation source, this model finds the critical initiation energy is linearly proportional to the cell width. In this way, we estimate the planar critical initiation energy is increased by two orders of magnitude if JP-10 is detonated in air rather than in oxygen.

\section{Decomposed JP-10 surrogate (HCS)}

Brabbs and Merritt [1] investigated the fuel-rich catalytic combustion of JP10 for a range of equivalence ratios. We have used their results to create a mixture similar to the decomposition products and tested this mixture in our detonation tube. The mixture (Table 1) resulted from JP-10 combustion at an equivalence ratio of 5.06, with a reaction temperature of $1220 \mathrm{~K}$. Group 
2 hydrocarbons are those with three or more carbon atoms. The remaining fraction consisted of condensible products which were not analyzed.

A hydrocarbon surrogate (HCS) blend was made by omitting the $\mathrm{O}_{2}$, $\mathrm{N}_{2}$ and $\mathrm{CO}_{2}$ from the mixture given in Table 1. Hexane was chosen as a representative larger hydrocarbon from Group 2. Four of the components of the blend $\left(\mathrm{H}_{2}, \mathrm{CO}, \mathrm{CH}_{4}\right.$, and $\left.\mathrm{C}_{2} \mathrm{H}_{4}\right)$ were premixed by the manufacturer to an accuracy of $\pm 2 \%$ on each component. This was done to improve the repeatability of the tests.

The HCS blend was mixed with a stoichiometric amount of $\mathrm{O}_{2}$ and diluted with $\mathrm{N}_{2}$. Experiments were performed at $295 \mathrm{~K}$ and at the maximum pressure possible in the facility. The pressure was limited by the design strength of the tube. Table A2 lists the mixture composition and initial conditions for the experiments. Cell widths were measured for several $\beta$ values (Fig. 8), and decrease from $27.6 \mathrm{~mm}$ for $\beta=3.76$ (i.e. HCS blend-air) to $1.0 \mathrm{~mm}$ for $\beta=0$ (i.e. HCS blend-oxygen). The cell width of HCS blend-air is about half that of JP-10-air, suggesting that catalytic combustion can be used to reduce the planar critical initiation energy of JP-10 by a factor of two. It should be noted, however, that $\mathrm{CO}_{2}$, which comprises $3 \%$ of the initial JP-10 decomposition products, was omitted in this study. 
The mixture with $\beta=4.66$ is the HCS blend together with the volume fraction of $\mathrm{O}_{2}$ and $\mathrm{N}_{2}$ remaining after catalytic combustion. Sufficient air is added so that the mixture is stoichiometric. Since there is excess $\mathrm{N}_{2}$ in the catalytic combustion products, this results in a value of $\beta$ greater than that of air. The cell width for this misture is $55.8 \mathrm{~mm}$ which is close to the $60.4 \mathrm{~mm}$ cell width measured for JP-10-air. If the HCS blend is mixed with a stoichiometric amount of $\mathrm{O}_{2}$, and no $\mathrm{N}_{2}$ is added beyond that which would remain after the catalytic combustion, $\beta=1$ and the extrapolated cell width at $100 \mathrm{kPa}$ is about $4 \mathrm{~mm}$.

A study was made of the effects of adding some fuels which result from JP-10 decomposition to JP-10-air. Cell widths measured in mixtures of JP-10 -air with $\mathrm{C}_{2} \mathrm{H}_{2}, \mathrm{C}_{2} \mathrm{H}_{4}$, and $\mathrm{CH}_{4}$ are presented in Fig. 9. Such measurements should be of value in validating reaction mechanisms suitable for JP-10. A more systematic study of the effectiveness of adding low-molecular weight fuels as sensitizers to heavy hydrocarbon fuels was carried out in hexane mixtures. 


\section{$\mathrm{C}_{6} \mathrm{H}_{14}$ mixtures with $\mathrm{O}_{2}-\mathrm{N}_{2}$}

The sensitivity of stoichiometric $\mathrm{C}_{6} \mathrm{H}_{14}-\mathrm{O}_{2}$ to nitrogen dilution was investigated. Since the reflected detonation pressure for these mixtures initially at $100 \mathrm{kPa}$ exceeded the facility limit, experiments were performed at $40 \mathrm{kPa}$ or at the highest initial pressure possible in the facility for each mixture. The cell width at an initial pressure of $100 \mathrm{kPa}$ was estimated from these two data points by assuming the cell width varies in inverse proportion to the initial pressure. The average cell width is plotted against $\beta$ in Fig. 10, where $\beta$ is the ratio of $\mathrm{N}_{2}$ to $\mathrm{O}_{2}$ concentration in the mixture $(\beta=3.76$ for air). The cell width increased from $1.7 \mathrm{~mm}$ at $\beta=0$ to $51.1 \mathrm{~mm}$ at $\beta=3.76$. Extrapolated cell widths were a factor of two smaller than those previously measured at $100 \mathrm{kPa}$ by Beeson et al. [10]; however the present experimental measurement at $100 \mathrm{kPa}$ agrees well with extrapolated values. Discrepancy between Beeson et al. and the present extrapolated results may be due to the differences in the facility size and initiation method. Also shown are data at elevated temperature from Tieszen et al. [6] and Zhang et al. [11].

A comparison was made between the hexane and other fuels (Table 2).

Cell widths obtained at different $\beta$ values are shown in Fig. 11 for $\mathrm{C}_{2} \mathrm{H}_{4}$, $\mathrm{C}_{3} \mathrm{H}_{8}$, and $\mathrm{CH}_{4}$, all at $295 \mathrm{~K}$ and $100 \mathrm{kPa}$. 'CIT' refers to unpublished cell 
width measurements previously made at Caltech in the GDT. Hexane cell widths also appear to be similar to those of propane.

\section{Sensitization of $\mathrm{C}_{6} \mathrm{H}_{14}$-air}

A series of investigations was made into the sensitizing effects of adding $\mathrm{H}_{2}$, $\mathrm{C}_{2} \mathrm{H}_{2}, \mathrm{C}_{2} \mathrm{H}_{4}$ or $\mathrm{CO}$ to $\mathrm{C}_{6} \mathrm{H}_{14}$ at $295 \mathrm{~K}$ and $100 \mathrm{kPa}$. The amount of sensitizer was calculated as a mass fraction in the sensitizer-hexane mixture. The appropriate amount of air was added to maintain a stoichiometric mixture. Results are shown in Figs. 12 to 15, with cell width plotted against the percentage (by fuel mass) of sensitizer in the fuel mixture. $\mathrm{H}_{2}, \mathrm{C}_{2} \mathrm{H}_{2}$, and $\mathrm{C}_{2} \mathrm{H}_{4}$ mixtures show a gradual decrease in cell width as the fraction of fuel additive increases; $\mathrm{H}_{2}$ and $\mathrm{C}_{2} \mathrm{H}_{2}$ are more effective than $\mathrm{C}_{2} \mathrm{H}_{4}$. There is no significant variation in cell width for mixtures containing $10-70 \%$ CO. In mixtures with $\mathrm{CO}$ fractions increasing beyond about $75 \%$, the cell width increases, indicating the $\mathrm{CO}$ acts as an inhibitor. Beyond about $95 \% \mathrm{CO}$, the cell width increases sharply. This agrees with the reaction zone length measurements of Lu et al. [12]. They report a sharp increase in reaction zone length in $\mathrm{H}_{2}-\mathrm{CO}-\mathrm{O}_{2}$ mixtures when the $\mathrm{CO}$ concentration exceeds $75 \%$ of the

total fuel volume (98\% of the total fuel mass). These results are reasonable 
in view of the sensitivity of $\mathrm{CO}$ mixtures to the presence of hydrogenous species, discussed in the next section.

\section{Addition of $\mathbf{H}_{2}, \mathrm{C}_{2} \mathrm{H}_{2}, \mathrm{C}_{2} \mathbf{H}_{4}$, and $\mathrm{C}_{6} \mathrm{H}_{14}$ to $\mathrm{CO}$-air}

Carbon monoxide is of fundamental importance as a principal intermediate product of hydrocarbon combustion. The reaction mechanism of CO oxidation is relatively simple and has been studied extensively [13]. In the presence of even trace amounts of hydrogen, the oxidation of CO takes place almost entirely by reaction (1) rather than by the spin-forbidden reaction (2).

$$
\begin{gathered}
\mathrm{CO}+\mathrm{OH} \rightarrow \mathrm{CO}_{2}+\mathrm{H} \\
\mathrm{CO}+\mathrm{O}+\mathrm{M} \rightarrow \mathrm{CO}_{2}+\mathrm{M}
\end{gathered}
$$

Early reseachers found a dramatic increase in the reactivity of carbon monoxide with the addition of water vapor or other substances containing hydrogen ([14], [15], [16]). The hydroxyl radical promotes oxidation and drastically reduces the induction time.

The sensitizing effect of hydrogen addition to CO mixtures for detonations has been reported by several researchers. Kistiakowsky and Kydd [17] used x-ray absorption, White and Moore [18] used interferometry, and Lu et 
al. [12] used schlieren photography to measure the detonation reaction zone length. The addition of $\mathrm{CO}$ to $\mathrm{H}_{2}$-air mixtures has been shown to increase the reaction zone length in numerical calculations by Magzumov et al. [19].

There are very little detonation cell width data available in CO mixtures. Some soot foils obtained in a narrow channel are reported in $\mathrm{Lu}$ [20]. Libouton et al. [21] looked at the addition of halocarbons to $\mathrm{CO}-\mathrm{H}_{2}-\mathrm{Ar}$ mixtures in a study of the effect of inhibitors on detonation velocity and structure. A study of the sensitizing effect of increasing $\mathrm{H}_{2}$ addition was also included. Some cell length data are reported, but were obtained in a narrow channel at low pressure.

Previous research has examined $\mathrm{CO}-\mathrm{O}_{2}-\mathrm{H}_{2}$ mixtures but the present study is the first systematic effort to investigate different fuel types and their effect on the cell width. The fuels $\mathrm{H}_{2}, \mathrm{C}_{2} \mathrm{H}_{2}, \mathrm{C}_{2} \mathrm{H}_{4}$, and $\mathrm{C}_{6} \mathrm{H}_{14}$ were chosen as representative of species important to hydrocarbon combustion and to study the effects of varying atomic hydrogen content and chemical structure. Detonation pressure, velocity and cell width measurements were made. All mixtures were stoichiometric and at an initial pressure of $100 \mathrm{kPa}$ and an initial temperature of 295 K. Gases used were C.P. grade (99\%) and no attempt was made to remove impurities. In these and all other experiments, 
"air" was formed from one mole $\mathrm{O}_{2}$ with 3.76 mole $\mathrm{N}_{2}$. This avoided using room air which contains uncontrolled quantities of moisture.

No detonation could be initiated in stoichiometric $\mathrm{CO}-\mathrm{O}_{2}$. The limiting fraction of $\mathrm{H}_{2}$ that was necessary to detonate $\mathrm{CO}$-air was found to be between 0 and $2 \%$ (of fuel volume). Since the mixture $\mathrm{CO}-2 \% \mathrm{H}_{2}$-air resulted in highly irregular cells, a nitrogen dilution series was performed in the mixture CO-5\% $\mathrm{H}_{2}$ (of fuel volume) with stoichiometric $\mathrm{O}_{2}$ (Fig. 16).

Cell width measurements were made for varying mixture fractions (presented as \% of total mixture volume) of $\mathrm{H}_{2}, \mathrm{C}_{2} \mathrm{H}_{2}, \mathrm{C}_{2} \mathrm{H}_{4}$ and $\mathrm{C}_{6} \mathrm{H}_{14}$ in CO-air (Fig. 17). In all cases, increasing the fraction of additive reduced the cell width. The decrease of cell width is largest for fuel addition of $\mathrm{H}_{2}$ and $\mathrm{C}_{2} \mathrm{H}_{2}$, followed by $\mathrm{C}_{2} \mathrm{H}_{4}$, then $\mathrm{C}_{6} \mathrm{H}_{14}$. This is consistent with results from Tieszen et al. [6] who report a decrease in the cell width with increasing C-C bond strength in hydrocarbon-air mixtures.

A detonation could be initiated in mixtures with only very small fractions of $\mathrm{C}_{6} \mathrm{H}_{14}$ (0.07\% of the total mixture). This was the lowest fraction attempted since we were limited by the accuracy of the gauge used during the filling process. These results agree with the previously mentioned studies that report the extreme sensitivity of $\mathrm{CO}$ oxidation to the presence of 
hydrogen. The hexane molecule contains more $\mathrm{H}$ atoms than the other hydrocarbons considered in this study. Therefore, in a mixture with a certain $\%$ fuel additive, hexane has the highest fuel hydrogen atom concentration, where fuel hydrogen atom concentration, $\left[\mathrm{H}_{f}\right]$, is defined as $\mathrm{n}$ times the fuel concentration for the fuel $\mathrm{C}_{m} \mathrm{H}_{n}$. Fig. 18 shows the measured cell width against $\mathrm{H}_{f}$ concentration normalized by the initial $\mathrm{CO}$ concentration.

\section{Reaction zone structure of $\mathrm{CO}-\mathrm{H}_{2} /$ hydrocarbon mix- tures}

Fig. 18 shows the measured cell width is not merely a function of the fuel hydrogen atom concentration but also depends on fuel type, particularly at low concentrations (e.g. $\left[\mathrm{H}_{f}\right] /[\mathrm{CO}]=0.04$ ). To investigate this dependence on fuel type, reaction zone parameters such as species mole fractions and temperature were calculated using detailed chemical kinetics mechanisms. Mechanisms were first validated by comparing ignition delay times calculated assuming a constant volume explosion with experimental shock tube ignition delay times for the same mixtures. Mechanisms were validated for $\mathrm{CO}-\mathrm{H}_{2}$ mixtures and also for mixtures involving the hydrocarbon for which they were considered. The mechanism of Warnatz and Karbach [22] (34 
species, 165 reactions) was chosen for mixtures containing $\mathrm{H}_{2}, \mathrm{C}_{2} \mathrm{H}_{2}$, and $\mathrm{C}_{2} \mathrm{H}_{4}$. The mechanism of Curran et al. [23] (550 species, 2500 reactions) was used for $\mathrm{C}_{6} \mathrm{H}_{14}$ mixtures. Some validations are shown in Figs. 19, 20, and 21. Both mechanisms perform very well against the $\mathrm{CO}-\mathrm{H}_{2}-\mathrm{O}_{2}$ data of Dean et al. [24]. The Curran mechanism underpredicts the experimental data of Burcat et al. [25] by a factor of two. Davidson et al. [26] compared ignition delay times calculated by the Curran mechanism with their shock tube data for heptane mixtures and found the same trends: the mechanism shows a similar temperature dependence as their data but the calculated ignition times are a factor of two shorter than the measured values. For acetylene mixtures, the Warnatz and Karbach mechanism was compared to the shock tube data of Edwards et al. [27] as these data are close to the detonation conditions (Fig. 21). At high temperature, the measured induction times are up to a factor of two greater than the calculated times. Recently, Varatharajan and Williams [28] found a similar underprediction when validating their mechanism against these data. A discussion of the range of validity of detailed reaction mechanisms for detonation conditions, possible sources of error in shock tube induction time data and the applicability of a constant volume calculation for the validation process is given in Schultz and Shepherd [29]. 
The validation of the Warnatz and Karbach mechanism for ethylene mixtures is also contained in that report.

A numerical solution of the one dimensional Zel'dovich-von NeumannDoring (ZND) model [30] was used together with the validated mechanisms and CHEMKIN II [31] chemical kinetics subroutines to calculate the variation of temperature and species concentrations through the reaction zone. Sample calculations of species mole fractions through the reaction zone for mixtures with $2 \%, 5 \%, 10 \%$ and $30 \% \mathrm{H}_{2}$ (by fuel fraction) are shown in Fig. 22. Two regions of $\left[\mathrm{H}_{f}\right] /[\mathrm{CO}]$ concentration are of interest: small values of $\left[\mathrm{H}_{f}\right] /[\mathrm{CO}]$ where the additive may play a sensitizing role, and large values of $\left[\mathrm{H}_{f}\right] /[\mathrm{CO}]$ where hydrogen or hydrocarbon fuel oxidation dominates the combustion chemistry. As the fraction of $\mathrm{H}_{2}$ increases, the peak amount of $\mathrm{OH}$ produced increases. The time at which the peak $\mathrm{OH}$ mole fraction occurs decreases with increasing $\mathrm{H}_{2}$ concentration. There is a difference of one order of magnitude in the time between the peak $\mathrm{OH}$ mole fractions in the $2 \%$ and $30 \%$ cases. Calculations were performed for the other mixtures studied and similar results were obtained.

The magnitude of the computed peak $\mathrm{OH}$ concentration is shown in Fig. 23 as a function of $\left[\mathrm{H}_{f}\right] /[\mathrm{CO}]$ ratio for all fuels. For small $\left[\mathrm{H}_{f}\right] /[\mathrm{CO}]$ 
ratios, all mixtures produce about the same peak $\mathrm{OH}$ mole fraction for a given $\left[\mathrm{H}_{f}\right] /[\mathrm{CO}]$ ratio. This indicates that the difference in cell size at small $\left[\mathrm{H}_{f}\right] /[\mathrm{CO}]$ ratio that was noted in Fig. 18 is not due to differences in the peak levels of $\mathrm{OH}$ mole fraction. The post-shock temperatures of these mixtures were also calculated and found to be almost identical.

With the addition of larger amounts of hydrogen or hydrocarbon, differences between the fuels become apparent. The calculated peak $\mathrm{OH}$ mole fraction is highest for $\mathrm{H}_{2}, \mathrm{C}_{2} \mathrm{H}_{2}$ and $\mathrm{C}_{2} \mathrm{H}_{4}$ addition; $\mathrm{C}_{6} \mathrm{H}_{14}$ mixtures produced the smallest peak mole fraction for a given $\left[\mathrm{H}_{f}\right] /[\mathrm{CO}]$ ratio. The species profiles for these $\mathrm{C}_{6} \mathrm{H}_{14}$ mixtures show a peak in the $\mathrm{CO}$ mole fraction profiles (Fig. 24), since with the addition of a large fraction of $\mathrm{C}_{6} \mathrm{H}_{14}, \mathrm{CO}$ is being produced by the $\mathrm{C}_{6} \mathrm{H}_{14}$ combustion.

In Fig. 22, differences can be observed in the time of the $\mathrm{OH}$ production. In view of this, the location of the peak $\mathrm{OH}$ mole fraction was investigated for the different fuels. Fig. 25 shows the location (relative to the shock front) of the calculated peak $\mathrm{OH}$ mole fraction as a function of the $\left[\mathrm{H}_{f}\right] /[\mathrm{CO}]$ ratio. This distance is greatest for mixtures with $\mathrm{C}_{6} \mathrm{H}_{14}$ addition and is smallest for mixtures with $\mathrm{C}_{2} \mathrm{H}_{2}$ addition. This correlation suggests that the differences in cell size between the additives may be explained by the differences in the 
location of the peak mole fraction of $\mathrm{OH}$.

The reaction zone length is typically defined as the distance between the shock and the location of the maximum temperature gradient and can be related to the cell width by a constant of proportionality, A. This constant is different for fuel- $\mathrm{O}_{2}$ and fuel-air mixtures [32] and also to varies with the equivalence ratio [30]. However, both reaction zone length and cell width are approximately proportional for a wide range of mixtures and can be related to the critical initiation energy [33], so that either parameter is a useful measure of the sensitivity of a mixture to detonation.

Fig. 26 shows the measured cell width versus the reaction zone length. In Fig. 26a, the reaction zone length is defined based on the temperature profile as described above. There are some significant deviations from the expected linear relationship. In view of the significant role of $\mathrm{OH}$ in the reaction process, we have also considered an alternate definition of the reaction zone length as the location of the peak in $\mathrm{OH}$ mole fraction. The correlation with measured cell width is significantly better (Fig. 26b) for the OH-based reaction zone length than for the usual temperature-based reaction zone length (Fig. 26a). Fitting the results of Fig. 26b to a linear correlation, values between 25 and 35 were obtained for A. These values are 
reasonable and similar to values of A obtained for other mixtures with the temperature-based definition of the reaction zone length ([30],[34]).

\section{Summary and Conclusions}

Detonation cell width measurements were made in a variety of hydrocarbon fuel mixtures of interest to aviation propulsion. Cell widths were measured in vapor-phase JP-10 mixtures at $353 \mathrm{~K}$, varying equivalence ratio, initial pressure and dilution, and found to be comparable to those of propane and hexane mixtures. This result suggests that propane may be used as a surrogate fuel for JP-10 for preliminary studies of pulse detonation engines.

A hydrocarbon fuel blend representative of the decomposition products of JP-10 after catalytic cracking was studied at $295 \mathrm{~K}$. The cell width of the fuel blend-air mixture is about half that of JP-10-air, indicating that the critical initiation energy is reduced by a factor of two if JP-10 is decomposed prior to injection into the combustion chamber. The minimum size of the chamber that is required for steady detonation propagation is also reduced by a factor of two. However, this is reduction in cell width occurs only

if JP-10 is catalytically combusted with oxygen. If the combustion is in 
air, and the JP-10 decomposition products (including the remaining $\mathrm{O}_{2}$ and $\mathrm{N}_{2}$ ) are mixed with air to make a stoichiometric mixture in the combustion chamber, the cell width $(55.8 \mathrm{~m})$ is approximately the same as the cell width for stoichiometric JP-10-air (60.4 mm).

Cell width measurements were made for mixtures of JP-10-air with $\mathrm{C}_{2} \mathrm{H}_{2}$, $\mathrm{C}_{2} \mathrm{H}_{4}, \mathrm{CH}_{4}$. Such data should be of use in validation studies for JP-10 reaction mechanisms.

The effectiveness of adding low-molecular weight hydrocarbon fuels, such as those resulting from JP-10 decomposition, to a representative liquid fuel, $\mathrm{C}_{6} \mathrm{H}_{14}$, was investigated. The addition of $\mathrm{H}_{2}, \mathrm{C}_{2} \mathrm{H}_{2}$, and $\mathrm{C}_{2} \mathrm{H}_{4}$ resulted in a decrease in the measured cell width, in order of decreasing effectiveness. Addition of $25 \% \mathrm{H}_{2}$ (by fuel mass) resulted in a $50 \%$ reduction in the cell width. These results show a considerable amount of low-molecular weight fuel must be added before a significant decrease is observed in the cell width. Addition of less than $10 \%$ CO reduced the cell size slightly and the presence of more than $75 \% \mathrm{CO}$ increased the cell size significantly. Between these limits, there was little effect on the cell width. Large quantities of CO may be produced by thermal or catalyic decomposition of liquid fuels. This study suggests that if $\mathrm{CO}$ is mixed with a vaporized liquid fuel, the effect on cell 
width may be neglected as long as CO is less than $75 \%$ of total fuel mass.

Mixtures of $\mathrm{CO}$ with hydrogen or hydrocarbon in air were also studied. For all mixtures studied, the addition of increasing amounts of hydrogen or hydrocarbon reduced the cell width. The greatest reduction was due to the addition of $\mathrm{C}_{2} \mathrm{H}_{2}$ and $\mathrm{H}_{2}$, followed by $\mathrm{C}_{2} \mathrm{H}_{4}$, then $\mathrm{C}_{6} \mathrm{H}_{14}$. Detonations could be initiated in mixtures with a very small fraction of $\mathrm{C}_{6} \mathrm{H}_{14}(0.07 \%$ of the total mixture). Temperature and radical species profiles were calculated through the reaction zone. Measured cell widths were compared with calculated reaction zone thicknesses. In these mixtures, if the reaction zone thickness is defined by the location of the peak in $\mathrm{OH}$ mole fraction, the cell width is directly proportional to the reaction zone thickness with slopes between 25 and 35 . This relationship may be used to estimate the detonation cell width from the calculated reaction zone thickness for these mixtures.

\section{Acknowledgements}

This work was partially performed in conjuction with the Air Force and Advanced Projects Research Inc., under contract F04611-98-C-0046, and partially with the Office of Naval Research Multidisciplinary University Research 
Initiative Multidisciplinary Study of Pulse Detonation Engine, grant 0001499-1-0744, subcontract 1686-ONR-0744. We would like to thank Tony Chao for design work in strengthening the facility, Eric Wintenberger for performing the vapor pressure measurements, and Florian Pintgen for his work with the heating system and assistance with JP-10 experiments.

\section{References}

[1] T.A. Brabbs and S.A. Merritt. Technical Report 3281, NASA, 1993.

[2] R. Akbar. PhD thesis, Rensselaer Polytechnic Institute, Troy, NY, 1997.

[3] R. Akbar, M.J. Kaneshige, E. Schultz, and J.E. Shepherd. Technical Report FM97-3, Graduate Aeronautical Laboratories: California Institute of Technology, 1997.

[4] P.A. Thibault, J.D. Penrose, J.E. Shepherd, W.B. Benedick, and D.V. Ritzel. Shock Tubes and Waves, pages 765-771, 1987.

[5] W.C. Reynolds. Technical Report A-3991, Dept. of Mechanical Engineering, Stanford University, Stanford, CA, January 1986.

[6] S.R. Tieszen, D.W. Stamps, C.K. Westbrook, and W.J. Pitz. Combust. Flame, 84:376-390, 1991.

[7] R. Akbar, P.A. Thibault, P.G. Harris, L.-S. Lussier, F. Zhang, S.B. Murray, and K. Gerrard. (AIAA-2000-3592), 2000.

[8] Ya.B. Zel'dovich, S.M. Kogarko, and N.N. Simonov. Soviet Phys. Tech. Phys., 1(8):1689-1713, 1956.

[9] J.H.S. Lee and K Ramamurthi. Combust. Flame, 27:331-340, 1976.

[10] H.D. Beeson, R.D. McClenagan, C.V. Bishop, F.J. Benz, W.J. Pitz, C.K. Westbrook, and J.H.S. Lee. Prog. Astronaut. Aeronaut, 133(1934), 1991. 
[11] F. Zhang, R. Akbar, P.A. Thibault, and S.B.Murray. Shock Waves, 10(6):457-466, 2001.

[12] P.L. Lu, E.K. Dabora, and J.A.Nicholls. Combust. Sci. Tech., 1:65-74, 1969.

[13] W.C. Gardiner. Gas-Phase Combustion Chemistry. Springer-Verlag, 2000.

[14] H.B. Dixon. Trans. Chem. Soc, page 759, 1896.

[15] G.B. Kistiakowsky, H.T. Knight, and M.E. Malin. J. Chem. Phys., 20(6):994-1000, 1952.

[16] B.F. Myers, K.G.P. Sulzmann, and E.R. Bartle. J. Chem. Phys., 43(4):1220-1228, 1965.

[17] G.B. Kistiakowsky and P.H. Kydd. J. Chem. Phys., 25(5):824-835, 1956.

[18] D.R. White and G.E. Moore. 10th Symp. (Int.) Combust., pages 785795, 1965.

[19] A.E. Magzumov, I.A. Kirillov, and V.D. Rusanov. Chem. Phys. Reports, 17(10):1961-1973, 1998.

[20] Pai-Lien Lu. PhD thesis, University of Michigan, 1968.

[21] J.C. Libouton, M. Dormal, and P.J. Van Tiggelen. 15th Symp. (Int.) Combust., pages 79-86, 1975.

[22] J. Warnatz and V. Karbach. http://www.ca.sandia.gov/tdf/3rdWorkshop/ch4mech.html, 1997.

[23] H.J. Curran, P. Gaffuri, W.J. Pitz, and C.K. Westbrook. A comprehensive modelling study of n-heptane oxidation. Combust. Flame, 114:149177, 1998.

[24] A.M. Dean, D.C. Steiner, and E.E. Wang. Combust. Flame, 32:73-83, 1978.

[25] A. Burcat, E. Olchanski, and C. Sokolinski. Israel Journal of Chemistry, 36:313-320, 1996. 
[26] D.F. Davidson, D.C. Horning, and R.K. Hanson. AIAA, (99-2216), 1999.

[27] D.H. Edwards, G.O. Thomas, and T.L. Williams. Combust. Flame, 43:187-198, 1981.

[28] B. Varatharajan and F.A. Williams. Combust. Flame, pages 624-645, 2001.

[29] E. Schultz and J.E. Shepherd. Technical Report FM99-5, Graduate Aeronautical Laboratories: California Institute of Technology, 2000.

[30] J.E. Shepherd. Prog. Astronaut. Aeronaut., 106:263-293, 1986.

[31] R. Kee, F. Rupley, and J. Miller. Technical Report SAND89-8009, Sandia National Laboratory, 1989.

[32] C.K. Westbrook. Combust. Flame, 46:191-210, 1982.

[33] J.H.S. Lee. Ann. Rev. Fluid Mech., 16:311-316, 1984.

[34] C.K. Westbrook and P.A. Urtiew. Fiz. Goreniya Vzryva, 19(6):65-76, 1983.

[35] I.O. Moen, J.W. Funk, S.A. Ward, G.M. Rude, and P.A. Thibault. Prog. Aeronaut. Astronaut., 94:55-79, 1984.

[36] R. Knystautas, J.H. Lee, and C.M.Guirao. Combust. Flame, 48(1):6383, 1982.

[37] J.E. Shepherd, C.J. Krok, and J.J. Lee. Technical Report FM97-5, Graduate Aeronautical Laboratories: California Institute of Technology, June 1997. 


\section{Table Captions}

Table 1: Products (by $\%$ volume) of JP-10 catalytic combustion at $\phi=5.06$, 1220K from Brabbs and Merritt [1].

Table 2: Comparison of cell width measurements of various stoichiometric fuel-air mixtures at $100 \mathrm{kPa}$.

Tables for Appendix A

Table A1: JP-10- $\mathrm{O}_{2}-\mathrm{N}_{2}$ mixtures with varying equivalence ration, initial pressure and $\mathrm{N}_{2}$ dilution. (Initial temperature $=353 \mathrm{~K}$, 'Air' $=\mathrm{O}_{2}+3.76 \mathrm{~N}_{2}$ )

Table A2: HCS mixtures

Table A3: JP-10-additive-air mixtures (Initial temperature $=353 \mathrm{~K}$, 'Air' ${ }^{\prime}=\mathrm{O}_{2}+3.76 \mathrm{~N}_{2}$ )

Table A4: $\mathrm{C}_{6} \mathrm{H}_{14}-\mathrm{O}_{2}-\mathrm{N}_{2}$ mixtures. (Initial temperature $=295 \mathrm{~K}$ )

Table A5: $\mathrm{C}_{6} \mathrm{H}_{14}$-additive-air mixtures. (Initial temperature $=295 \mathrm{~K}$, 'Air' $=\mathrm{O}_{2}+3.76 \mathrm{~N}_{2}$ )

Table A6: CO mixtures.('Air' $=\mathrm{O}_{2}+3.76 \mathrm{~N}_{2} \cdot{ }^{a}$ : cells unreadable) 


\begin{tabular}{|ccccccccc|}
\hline $\mathrm{CO}_{2}$ & $\mathrm{H}_{2}$ & $\mathrm{CO}$ & $\mathrm{CH}_{4}$ & $\mathrm{C}_{2} \mathrm{H}_{2}$ & $\mathrm{C}_{2} \mathrm{H}_{4}$ & Group 2 & $\mathrm{O}_{2}$ & $\mathrm{~N}_{2}$ \\
\hline 3.37 & 8.07 & 14.70 & 2.88 & 0.73 & 4.24 & 3.03 & 1.38 & 60.79 \\
\hline
\end{tabular}

Table 1:

\begin{tabular}{|c|c|c|}
\hline Fuel & Cell width $(\mathrm{mm})$ & Reference \\
\hline $\mathrm{H}_{2}$ & 10.9 & CIT \\
$\mathrm{CH}_{4}$ & 280 & {$[35]$} \\
$\mathrm{C}_{2} \mathrm{H}_{2}$ & 10 & {$[36]$} \\
$\mathrm{C}_{2} \mathrm{H}_{4}$ & 22.8 & CIT \\
$\mathrm{C}_{3} \mathrm{H}_{8}$ & 51.3 & CIT \\
$\mathrm{C}_{6} \mathrm{H}_{14}$ & 51.1 & CIT \\
\hline
\end{tabular}

Table 2: 


\begin{tabular}{|ccccc|}
\hline Mixture & $\mathrm{P}_{o}$ & \multicolumn{3}{c|}{$\lambda(\mathrm{mm})$} \\
& $(\mathrm{kPa})$ & av & max. & min. \\
\hline $0.7 \mathrm{C}_{10} \mathrm{H}_{16}-14$ Air & 100 & 138.5 & 240 & 52 \\
$0.8 \mathrm{C}_{10} \mathrm{H}_{16}-14$ Air & 100 & 65.9 & 72 & 52 \\
$0.85 \mathrm{C}_{10} \mathrm{H}_{16}-14$ Air & 100 & 57.4 & 66 & 39 \\
$0.9 \mathrm{C}_{10} \mathrm{H}_{16}-14$ Air & 100 & 52.9 & 60 & 44 \\
$0.95 \mathrm{C}_{10} \mathrm{H}_{16}-14$ Air & 100 & 44.4 & 57 & 33 \\
$1.0 \mathrm{C}_{10} \mathrm{H}_{16}-14$ Air & 100 & 65.8 & 84 & 40 \\
$1.0 \mathrm{C}_{10} \mathrm{H}_{16}-14$ Air & 100 & 54.9 & 61 & 39 \\
$1.1 \mathrm{C}_{10} \mathrm{H}_{16}-14$ Air & 100 & 56.8 & 88 & 44 \\
$1.1 \mathrm{C}_{10} \mathrm{H}_{16}-14$ Air & 100 & 56.0 & 71 & 41 \\
$1.15 \mathrm{C}_{10} \mathrm{H}_{16}-14 \mathrm{Air}$ & 100 & 41.9 & 49 & 25 \\
$1.2 \mathrm{C}_{10} \mathrm{H}_{16}-14$ Air & 100 & 48.9 & 71 & 33 \\
$1.25 \mathrm{C}_{10} \mathrm{H}_{16}-14 \mathrm{Air}$ & 100 & 49.6 & 62 & 38 \\
$1.3 \mathrm{C}_{10} \mathrm{H}_{16}-14 \mathrm{Air}$ & 100 & 41.9 & 49 & 36 \\
$1.35 \mathrm{C}_{10} \mathrm{H}_{16}-14 \mathrm{Air}$ & 100 & 78.5 & 134 & 34 \\
$1.4 \mathrm{C}_{10} \mathrm{H}_{16}-14 \mathrm{Air}$ & 100 & 74.1 & 99 & 40 \\
$\mathrm{C}_{10} \mathrm{H}_{16}-14 \mathrm{Air}$ & 63.5 & 100.9 & 165 & 54 \\
$\mathrm{C}_{10} \mathrm{H}_{16}-14 \mathrm{Air}$ & 130 & 40.8 & 54 & 29 \\
$\mathrm{C}_{10} \mathrm{H}_{16}-14 \mathrm{O}_{2}$ & 20 & 4.6 & 6 & 3 \\
$\mathrm{C}_{10} \mathrm{H}_{16}-14 \mathrm{O}_{2}$ & 50 & 2.0 & 3 & 1 \\
$\mathrm{C}_{10} \mathrm{H}_{16}-14\left(\mathrm{O}_{2}-0.75 \mathrm{~N}_{2}\right)$ & 100 & 5.1 & 7 & 3 \\
$\mathrm{C}_{10} \mathrm{H}_{16}-14\left(\mathrm{O}_{2}-1.5 \mathrm{~N}_{2}\right)$ & 100 & 9.3 & 13 & 5 \\
$\mathrm{C}_{10} \mathrm{H}_{16}-14\left(\mathrm{O}_{2}-2.25 \mathrm{~N}_{2}\right)$ & 100 & 19.4 & 22 & 14 \\
$\mathrm{C}_{10} \mathrm{H}_{16}-14\left(\mathrm{O}_{2}-3 \mathrm{~N}_{2}\right)$ & 100 & 43.6 & 68 & 29 \\
\hline
\end{tabular}




\begin{tabular}{|ccccccccccc|}
\hline \multicolumn{1}{|c|}{ Mixture Fractions } \\
$\mathrm{H}_{2}$ & $\mathrm{CO}$ & $\mathrm{CH}_{4}$ & $\mathrm{C}_{2} \mathrm{H}_{2}$ & $\mathrm{C}_{2} \mathrm{H}_{4}$ & $\mathrm{C}_{6} \mathrm{H}_{14}$ & $\mathrm{O}_{2}$ & $\mathrm{~N}_{2}$ & $(\mathrm{kPa})$ & & $(\mathrm{mm})$ \\
\hline 0.025 & 0.046 & 0.009 & 0.002 & 0.013 & 0.009 & 0.188 & 0.707 & 100 & 3.76 & 27.6 \\
0.03 & 0.053 & 0.011 & 0.003 & 0.015 & 0.011 & 0.219 & 0.658 & 100 & 3.0 & 15.5 \\
0.035 & 0.064 & 0.013 & 0.003 & 0.018 & 0.013 & 0.262 & 0.591 & 90 & 2.25 & 10.6 \\
0.044 & 0.080 & 0.016 & 0.004 & 0.023 & 0.016 & 0.327 & 0.490 & 85 & 1.5 & 6.4 \\
0.058 & 0.105 & 0.021 & 0.005 & 0.030 & 0.022 & 0.433 & 0.345 & 75 & 0.75 & 2.9 \\
0.087 & 0.157 & 0.031 & 0.007 & 0.045 & 0.032 & 0.641 & 0.0 & 65 & 0.0 & 1.5 \\
0.021 & 0.039 & 0.007 & 0.002 & 0.008 & 0.008 & 0.161 & 0.751 & 100 & 4.66 & 55.8 \\
\hline
\end{tabular}




\begin{tabular}{|ccccc|}
\hline Mixture & $\mathrm{P}_{o}$ & \multicolumn{3}{c|}{$\lambda(\mathrm{mm})$} \\
& $(\mathrm{kPa})$ & av & $\max$ & $\min$ \\
\hline $0.9 \mathrm{C}_{10} \mathrm{H}_{16}-0.1 \mathrm{C}_{2} \mathrm{H}_{2}-12.85 \mathrm{Air}$ & 100 & 46.1 & 54 & 38 \\
$0.8 \mathrm{C}_{10} \mathrm{H}_{16}-0.2 \mathrm{C}_{2} \mathrm{H}_{2}-11.7$ Air & 100 & 39.4 & 53 & 30 \\
$0.7 \mathrm{C}_{10} \mathrm{H}_{16}-0.3 \mathrm{C}_{2} \mathrm{H}_{2}-10.55 \mathrm{Air}$ & 100 & 41.9 & 47 & 37 \\
$0.5 \mathrm{C}_{10} \mathrm{H}_{16}-0.5 \mathrm{C}_{2} \mathrm{H}_{2}-8.25 \mathrm{Air}$ & 100 & 34.9 & 43 & 28 \\
$0.3 \mathrm{C}_{10} \mathrm{H}_{16}-0.7 \mathrm{C}_{2} \mathrm{H}_{2}-5.95 \mathrm{Air}$ & 100 & 30.6 & 33 & 22 \\
$0.15 \mathrm{C}_{10} \mathrm{H}_{16}-0.85 \mathrm{C}_{2} \mathrm{H}_{2}-4.23 \mathrm{Air}$ & 100 & 15.3 & 20 & 11 \\
$\mathrm{C}_{2} \mathrm{H}_{2}-2.5 \mathrm{Air}$ & 100 & 4.0 & 6 & 3 \\
$0.9 \mathrm{C}_{10} \mathrm{H}_{16}-0.1 \mathrm{C}_{2} \mathrm{H}_{4}-12.9$ Air & 100 & 48.0 & 58 & 38 \\
$0.85 \mathrm{C}_{10} \mathrm{H}_{16}-0.15 \mathrm{C}_{2} \mathrm{H}_{4}-12.35 \mathrm{Air}$ & 100 & 43.0 & 50 & 33 \\
$0.5 \mathrm{C}_{10} \mathrm{H}_{16}-0.5 \mathrm{C}_{2} \mathrm{H}_{4}-8.5 \mathrm{Air}$ & 100 & 40.7 & 50 & 35 \\
$0.9 \mathrm{C}_{10} \mathrm{H}_{16}-0.1 \mathrm{CH}_{4}-12.8 \mathrm{Air}$ & 100 & 45.9 & 61 & 36 \\
$0.8 \mathrm{C}_{10} \mathrm{H}_{16}-0.2 \mathrm{CH}_{4}-11.6$ Air & 100 & 48.6 & 57 & 38 \\
$0.7 \mathrm{C}_{10} \mathrm{H}_{16}-0.3 \mathrm{CH}_{4}-10.4 \mathrm{Air}$ & 100 & 47.7 & 59 & 38 \\
$0.5 \mathrm{C}_{10} \mathrm{H}_{16}-0.5 \mathrm{CH}_{4}-8$ Air & 100 & 60.6 & 70 & 46 \\
\hline
\end{tabular}

\begin{tabular}{|ccccc|}
\hline Mixture & $\mathrm{P}_{o}$ & \multicolumn{3}{c|}{$\lambda(\mathrm{mm})$} \\
& $(\mathrm{kPa})$ & av & $\max$ & $\min$ \\
\hline $\mathrm{C}_{6} \mathrm{H}_{14}+9.5 \mathrm{O}_{2}$ & 40 & 1.7 & 2 & 1 \\
$\mathrm{C}_{6} \mathrm{H}_{14}+9.5\left(\mathrm{O}_{2}+0.75 \mathrm{~N}_{2}\right)$ & 40 & 6.3 & 8 & 5 \\
$\mathrm{C}_{6} \mathrm{H}_{14}+9.5\left(\mathrm{O}_{2}+1.5 \mathrm{~N}_{2}\right)$ & 40 & 16.0 & 19 & 14 \\
$\mathrm{C}_{6} \mathrm{H}_{14}+9.5\left(\mathrm{O}_{2}+2.25 \mathrm{~N}_{2}\right)$ & 40 & 30.4 & 41 & 22 \\
$\mathrm{C}_{6} \mathrm{H}_{14}+9.5\left(\mathrm{O}_{2}+3.0 \mathrm{~N}_{2}\right)$ & 40 & 50.5 & 65 & 37 \\
$\mathrm{C}_{6} \mathrm{H}_{14}+9.5\left(\mathrm{O}_{2}+3.76 \mathrm{~N}_{2}\right)$ & 40 & 91.7 & 98 & 87 \\
$\mathrm{C}_{6} \mathrm{H}_{14}+9.5\left(\mathrm{O}_{2}+0.75 \mathrm{~N}_{2}\right)$ & 55 & 6.1 & 8 & 4 \\
$\mathrm{C}_{6} \mathrm{H}_{14}+9.5\left(\mathrm{O}_{2}+1.5 \mathrm{~N}_{2}\right)$ & 70 & 8.3 & 10 & 6 \\
$\mathrm{C}_{6} \mathrm{H}_{14}+9.5\left(\mathrm{O}_{2}+2.25 \mathrm{~N}_{2}\right)$ & 80 & 19.7 & 24 & 15 \\
$\mathrm{C}_{6} \mathrm{H}_{14}+9.5\left(\mathrm{O}_{2}+3.0 \mathrm{~N}_{2}\right)$ & 90 & 23.7 & 32 & 20 \\
$\mathrm{C}_{6} \mathrm{H}_{14}+9.5\left(\mathrm{O}_{2}+3.76 \mathrm{~N}_{2}\right)$ & 100 & 51.1 & 62 & 43 \\
\hline
\end{tabular}




\begin{tabular}{|c|c|c|c|c|}
\hline \multirow[t]{2}{*}{ Mixture } & \multirow{2}{*}{$\begin{array}{c}\mathrm{P}_{o} \\
(\mathrm{kPa})\end{array}$} & \multicolumn{3}{|c|}{$\lambda(\mathrm{mm})$} \\
\hline & & av & $\max$ & $\min$ \\
\hline $\mathrm{C}_{6} \mathrm{H}_{14}+9.5 \mathrm{Air}$ & 100 & 51.1 & 62 & 43 \\
\hline $0.95 \mathrm{C}_{6} \mathrm{H}_{14}+0.05 \mathrm{H}_{2}+9.05 \mathrm{Air}$ & 100 & 39.2 & 53 & 28 \\
\hline $0.9 \mathrm{C}_{6} \mathrm{H}_{14}+0.1 \mathrm{H}_{2}+8.6 \mathrm{Air}$ & 100 & 43.2 & 49 & 38 \\
\hline $0.8 \mathrm{C}_{6} \mathrm{H}_{14}+0.2 \mathrm{H}_{2}+7.7 \mathrm{Air}$ & 100 & 42.7 & 55 & 31 \\
\hline $0.7 \mathrm{C}_{6} \mathrm{H}_{14}+0.3 \mathrm{H}_{2}+6.8 \mathrm{Air}$ & 100 & 39.5 & 46 & 31 \\
\hline $0.6 \mathrm{C}_{6} \mathrm{H}_{14}+0.4 \mathrm{H}_{2}+5.9 \mathrm{Air}$ & 100 & 38.5 & 46 & 29 \\
\hline $0.5 \mathrm{C}_{6} \mathrm{H}_{14}+0.5 \mathrm{H}_{2}+5.0 \mathrm{Air}$ & 100 & 34.9 & 45 & 29 \\
\hline $0.1 \mathrm{C}_{6} \mathrm{H}_{14}+0.9 \mathrm{H}_{2}+1.4 \mathrm{Air}$ & 100 & 27.3 & 33 & 22 \\
\hline $0.05 \mathrm{C}_{6} \mathrm{H}_{14}+0.95 \mathrm{H}_{2}+0.95$ Air & 100 & 21.9 & 27 & 19 \\
\hline $0.02 \mathrm{C}_{6} \mathrm{H}_{14}+0.98 \mathrm{H}_{2}+0.68$ Air & 100 & 13.5 & 16 & 11 \\
\hline $0.01 \mathrm{C}_{6} \mathrm{H}_{14}+0.99 \mathrm{H}_{2}+0.59$ Air & 100 & 10.1 & 13 & 7 \\
\hline $\mathrm{H}_{2}+0.5 \mathrm{Air}$ & 100 & 10.9 & 12 & 9 \\
\hline $0.9 \mathrm{C}_{6} \mathrm{H}_{14}+0.1 \mathrm{C}_{2} \mathrm{H}_{2}+8.8 \mathrm{Air}$ & 100 & 36.8 & 42 & 29 \\
\hline $0.7 \mathrm{C}_{6} \mathrm{H}_{14}+0.3 \mathrm{C}_{2} \mathrm{H}_{2}+7.4 \mathrm{Air}$ & 100 & 31.4 & 36 & 25 \\
\hline $0.5 \mathrm{C}_{6} \mathrm{H}_{14}+0.5 \mathrm{C}_{2} \mathrm{H}_{2}+6.0$ Air & 100 & 32.2 & 39 & 25 \\
\hline $0.3 \mathrm{C}_{6} \mathrm{H}_{14}+0.7 \mathrm{C}_{2} \mathrm{H}_{2}+4.6 \mathrm{Air}$ & 100 & 20.7 & 23 & 17 \\
\hline $0.2 \mathrm{C}_{6} \mathrm{H}_{14}+0.8 \mathrm{C}_{2} \mathrm{H}_{2}+3.9 \mathrm{Air}$ & 100 & 14.1 & 16 & 12 \\
\hline $0.1 \mathrm{C}_{6} \mathrm{H}_{14}+0.9 \mathrm{C}_{2} \mathrm{H}_{2}+3.2 \mathrm{Air}$ & 100 & 10.7 & 14 & 8 \\
\hline $0.05 \mathrm{C}_{6} \mathrm{H}_{14}+0.95 \mathrm{C}_{2} \mathrm{H}_{2}+2.85 \mathrm{Air}$ & 100 & 8.4 & 12 & 6 \\
\hline $\mathrm{C}_{2} \mathrm{H}_{2}+2.5 \mathrm{Air}$ & 100 & 6.2 & 8 & 4 \\
\hline $0.9 \mathrm{C}_{6} \mathrm{H}_{14}+0.1 \mathrm{C}_{2} \mathrm{H}_{4}+8.85 \mathrm{Air}$ & 100 & 46.4 & 59 & 41 \\
\hline $0.8 \mathrm{C}_{6} \mathrm{H}_{14}+0.2 \mathrm{C}_{2} \mathrm{H}_{4}+8.2 \mathrm{Air}$ & 100 & 35.3 & 44 & 29 \\
\hline $0.7 \mathrm{C}_{6} \mathrm{H}_{14}+0.3 \mathrm{C}_{2} \mathrm{H}_{4}+7.55$ Air & 100 & 37.7 & 50 & 32 \\
\hline $0.6 \mathrm{C}_{6} \mathrm{H}_{14}+0.4 \mathrm{C}_{2} \mathrm{H}_{4}+6.9 \mathrm{Air}$ & 100 & 35.8 & 42 & 27 \\
\hline $0.5 \mathrm{C}_{6} \mathrm{H}_{14}+0.5 \mathrm{C}_{2} \mathrm{H}_{4}+6.25 \mathrm{Air}$ & 100 & 36.4 & 42 & 31 \\
\hline $0.3 \mathrm{C}_{6} \mathrm{H}_{14}+0.7 \mathrm{C}_{2} \mathrm{H}_{4}+4.95 \mathrm{Air}$ & 100 & 24.7 & 34 & 19 \\
\hline $0.2 \mathrm{C}_{6} \mathrm{H}_{14}+0.8 \mathrm{C}_{2} \mathrm{H}_{4}+4.3 \mathrm{Air}$ & 100 & 24.7 & 32 & 19 \\
\hline $0.1 \mathrm{C}_{6} \mathrm{H}_{14}+0.9 \mathrm{C}_{2} \mathrm{H}_{4}+3.65$ Air & 100 & 20.6 & 24 & 16 \\
\hline $0.05 \mathrm{C}_{6} \mathrm{H}_{14}+0.95 \mathrm{C}_{2} \mathrm{H}_{4}+3.33 \mathrm{Air}$ & 100 & 19.2 & 23 & 16 \\
\hline $0.02 \mathrm{C}_{6} \mathrm{H}_{14}+0.98 \mathrm{C}_{2} \mathrm{H}_{4}+3.13 \mathrm{Air}$ & 100 & 17.0 & 20 & 14 \\
\hline $\mathrm{C}_{2} \mathrm{H}_{4}+3 \mathrm{Air}$ & 100 & 22.8 & 29 & 19 \\
\hline
\end{tabular}




\begin{tabular}{|c|c|c|c|c|}
\hline \multirow[t]{2}{*}{ Mixture } & \multirow{2}{*}{$\begin{array}{c}\mathrm{P}_{o} \\
(\mathrm{kPa})\end{array}$} & \multicolumn{3}{|c|}{$\lambda(\mathrm{mm})$} \\
\hline & & av & $\max$ & $\min$ \\
\hline $9.5 \mathrm{CO}+0.5 \mathrm{H}_{2}+5 \mathrm{O}_{2}$ & 100 & 5.0 & 7 & 2 \\
\hline $9.5 \mathrm{CO}+0.5 \mathrm{H}_{2}+5\left(\mathrm{O}_{2}+1.5 \mathrm{~N}_{2}\right)$ & 100 & 12.5 & 16 & 10 \\
\hline $9.5 \mathrm{CO}+0.5 \mathrm{H}_{2}+5 \mathrm{Air}$ & 100 & 48.4 & 57 & 41 \\
\hline $0.995 \mathrm{CO}+0.005 \mathrm{H}_{2}+0.5 \mathrm{Air}$ & 100 & no det. & - & - \\
\hline $0.99 \mathrm{CO}+0.01 \mathrm{H}_{2}+0.5 \mathrm{Air}$ & 100 & no det. & - & - \\
\hline $0.99 \mathrm{CO}+0.01 \mathrm{H}_{2}+0.5 \mathrm{Air}$ & 100 & $\operatorname{det}^{a}$ & - & - \\
\hline $0.99 \mathrm{CO}+0.01 \mathrm{H}_{2}+0.5 \mathrm{Air}$ & 100 & no det. & - & - \\
\hline $0.98 \mathrm{CO}+0.02 \mathrm{H}_{2}+0.5 \mathrm{Air}$ & 100 & 100.3 & 121 & 87 \\
\hline $0.95 \mathrm{CO}+0.05 \mathrm{H}_{2}+0.5 \mathrm{Air}$ & 100 & 48.4 & 57 & 41 \\
\hline $0.9 \mathrm{CO}+0.1 \mathrm{H}_{2}+0.5 \mathrm{Air}$ & 100 & 32 & 43 & 21 \\
\hline $0.7 \mathrm{CO}+0.3 \mathrm{H}_{2}+0.5 \mathrm{Air}$ & 100 & 16.9 & 21 & 12 \\
\hline $0.995 \mathrm{CO}+0.005 \mathrm{C}_{2} \mathrm{H}_{2}+0.51 \mathrm{Air}$ & 100 & no det. & - & - \\
\hline $0.995 \mathrm{CO}+0.005 \mathrm{C}_{2} \mathrm{H}_{2}+0.51 \mathrm{Air}$ & 100 & 102.3 & 140 & 83 \\
\hline $0.99 \mathrm{CO}+0.01 \mathrm{C}_{2} \mathrm{H}_{2}+0.52 \mathrm{Air}$ & 100 & 90.5 & 115 & 62 \\
\hline $0.98 \mathrm{CO}+0.02 \mathrm{C}_{2} \mathrm{H}_{2}+0.54$ Air & 100 & 49.5 & 63 & 40 \\
\hline $0.95 \mathrm{CO}+0.05 \mathrm{C}_{2} \mathrm{H}_{2}+0.6 \mathrm{Air}$ & 100 & 29.9 & 34 & 27 \\
\hline $0.8 \mathrm{CO}+0.2 \mathrm{C}_{2} \mathrm{H}_{2}+0.9 \mathrm{Air}$ & 100 & 10.9 & 13 & 9 \\
\hline $0.995 \mathrm{CO}+0.005 \mathrm{C}_{2} \mathrm{H}_{4}+0.513 \mathrm{Air}$ & 100 & no det. & - & - \\
\hline $0.995 \mathrm{CO}+0.005 \mathrm{C}_{2} \mathrm{H}_{4}+0.513 \mathrm{Air}$ & 100 & no det. & - & - \\
\hline $0.99 \mathrm{CO}+0.01 \mathrm{C}_{2} \mathrm{H}_{4}+0.525 \mathrm{Air}$ & 100 & 71.8 & 114 & 49 \\
\hline $0.99 \mathrm{CO}+0.01 \mathrm{C}_{2} \mathrm{H}_{4}+0.525 \mathrm{Air}$ & 100 & 89.7 & 104 & 85 \\
\hline $0.98 \mathrm{CO}+0.02 \mathrm{C}_{2} \mathrm{H}_{4}+0.55 \mathrm{Air}$ & 100 & 54.3 & 74 & 45 \\
\hline $0.97 \mathrm{CO}+0.03 \mathrm{C}_{2} \mathrm{H}_{4}+0.575 \mathrm{Air}$ & 100 & 43.8 & 62 & 32 \\
\hline $0.95 \mathrm{CO}+0.05 \mathrm{C}_{2} \mathrm{H}_{4}+0.625 \mathrm{Air}$ & 100 & 36.2 & 63 & 26 \\
\hline $0.9 \mathrm{CO}+0.1 \mathrm{C}_{2} \mathrm{H}_{4}+0.75 \mathrm{Air}$ & 100 & 33.8 & 39 & 27 \\
\hline $0.7 \mathrm{CO}+0.3 \mathrm{C}_{2} \mathrm{H}_{4}+1.25 \mathrm{Air}$ & 100 & 25.2 & 33 & 18 \\
\hline $0.997 \mathrm{CO}+0.003 \mathrm{C}_{6} \mathrm{H}_{14}+0.527 \mathrm{Air}$ & 100 & 112.0 & 124 & 95 \\
\hline $0.995 \mathrm{CO}+0.005 \mathrm{C}_{6} \mathrm{H}_{14}+0.545 \mathrm{Air}$ & 100 & 89.4 & 95 & 82 \\
\hline $0.992 \mathrm{CO}+0.008 \mathrm{C}_{6} \mathrm{H}_{14}+0.572 \mathrm{Air}$ & 100 & 69.7 & 82 & 58 \\
\hline $0.99 \mathrm{CO}+0.01 \mathrm{C}_{6} \mathrm{H}_{14}+0.59$ Air & 100 & no det. & - & - \\
\hline $0.988 \mathrm{CO}+0.012 \mathrm{C}_{6} \mathrm{H}_{14}+0.608 \mathrm{Air}$ & 100 & 61.8 & 79 & 54 \\
\hline $0.985 \mathrm{CO}+0.015 \mathrm{C}_{6} \mathrm{H}_{14}+0.635 \mathrm{Air}$ & 100 & 58.3 & 74 & 46 \\
\hline $0.98 \mathrm{CO}+0.02 \mathrm{C}_{6} \mathrm{H}_{14}+0.68$ Air & 100 & 52.2 & 61 & 45 \\
\hline $0.95 \mathrm{CO}+0.05 \mathrm{C}_{6} \mathrm{H}_{14}+0.95$ Air & 100 & 43.1 & 51 & 39 \\
\hline $0.9 \mathrm{CO}+0.1 \mathrm{C}_{6} \mathrm{H}_{14}+1.4 \mathrm{Air}$ & 100 & 40.0 & 45 & 35 \\
\hline $0.7 \mathrm{CO}+0.3 \mathrm{C}_{6} \mathrm{H}_{14}+3.2 \mathrm{Air}$ & 100 & 36.7 & 45 & 29 \\
\hline $0.5 \mathrm{CO}+0.5 \mathrm{C}_{6} \mathrm{H}_{14}+5.0$ Air & 100 & 34.3 & 39 & 29 \\
\hline $0.3 \mathrm{CO}+0.7 \mathrm{C}_{6} \mathrm{H}_{14}+6.8 \mathrm{Air}$ & 100 & 36.9 & 43 & 28 \\
\hline $0.1 \mathrm{CO}+0.9 \mathrm{C}_{6} \mathrm{H}_{14}+8.6 \mathrm{Air}$ & 100 & 35.1 & 42 & 28 \\
\hline
\end{tabular}




\section{Figure Captions}

Figure 1: GALCIT $280 \mathrm{~mm}$ diameter gaseous detonation facility.

Figure 2: Measured vapor pressure curve for JP-10. Error bars reflect the accuracy of the temperature and pressure gauges. The measurement procedure is as described in Shepherd et al. [37].

Figure 3: Example pressure histories are shown. On the left, Fig. 3(a), the mixture is $0.98 \mathrm{CO}+0.02 \mathrm{H}_{2}+0.5 \mathrm{Air}$, at $100 \mathrm{kPa}$ initial pressure. The average cell width for this mixture is $100.3 \mathrm{~mm}$. On the right, Fig 3(b), the mixture is $0.9 \mathrm{CO}+0.05 \mathrm{H}_{2}+0.5 \mathrm{Air}$, at $100 \mathrm{kPa}$ initial pressure. The average cell width is $32 \mathrm{~mm}$.

Figure 4: Measured and calculated wave speeds for JP-10-air mixtures with varying equivalence ratio. Measured wave speeds are the average of speeds obtained from three transducers located along the tube as shown in Fig. 1.

Figure 5: Measured cell width in JP-10-air with varying equivalence ratio. Comparison is made with data for propane mixtures.

Figure 6: Measured cell widths in JP-10-air and JP-10- $\mathrm{O}_{2}$ with varying initial pressure.

Figure 7: Measured cell widths in $\mathrm{JP}-10-\mathrm{O}_{2}$ with varying $\mathrm{N}_{2}$ dilution up to a concentration equivalent to air, where $\beta$ is the ratio of $\mathrm{N}_{2}$ to $\mathrm{O}_{2}$ concentration. Initial pressure is $100 \mathrm{kPa}$, except where noted.

Figure 8: Cell width measurements for $\mathrm{N}_{2}$ dilution of a hydrocarbon blend representative of decomposed JP-10. The initial pressure was increased with increasing $\mathrm{N}_{2}$ dilution.

Figure 9: Measured cell widths in JP-10 with addition of $\mathrm{C}_{2} \mathrm{H}_{2}, \mathrm{C}_{2} \mathrm{H}_{4}$, and $\mathrm{CH}_{4}$. Data points at 100\% fuel additive are from Tieszen et al. [6]. Tieszen et al. [6] also report the cell width in $\mathrm{CH}_{4}$-Air to be $260 \mathrm{~mm}$.

Figure 10: Cell width measurements for $\mathrm{N}_{2}$ dilution of $\mathrm{C}_{6} \mathrm{H}_{14}-\mathrm{O}_{2}$ mixtures. 
Figure 11: Comparison of cell width measurements for $\mathrm{N}_{2}$ dilution of $\mathrm{CH}_{4}$, $\mathrm{C}_{2} \mathrm{H}_{4}, \mathrm{C}_{3} \mathrm{H}_{8}$ and $\mathrm{C}_{6} \mathrm{H}_{14}-\mathrm{O}_{2}$ mixtures. $\mathrm{C}_{6} \mathrm{H}_{14}$ data is the same as that presented in Fig. 10.

Figure 12: Cell width measurements for $\mathrm{H}_{2}$ addition to $\mathrm{C}_{6} \mathrm{H}_{14}$ in air.

Figure 13: Cell width measurements for $\mathrm{C}_{2} \mathrm{H}_{2}$ addition to $\mathrm{C}_{6} \mathrm{H}_{14}$ in air.

Figure 14: Cell width measurements for $\mathrm{C}_{2} \mathrm{H}_{4}$ addition to $\mathrm{C}_{6} \mathrm{H}_{14}$ in air.

Figure 15: Cell width measurements for $\mathrm{CO}$ addition to $\mathrm{C}_{6} \mathrm{H}_{14}$ in air.

Figure 16: Cell width measurements for $\mathrm{N}_{2}$ dilution of stoichiometric CO$5 \%$ (of fuel volume) $\mathrm{H}_{2}-\mathrm{O}_{2}$.

Figure 17: Cell width measurements for hydrogen or hydrocarbon addition to CO-air mixtures. Curves are interpolated from the cell widths of successful detonations. Error bars represent minimum and maximum measured cell widths. The detonation limit denotes a mixture where at least one failure was observed. About three experiments were performed for each mixture that failed to detonate.

Figure 18: Measured cell width as a function of $\left[\mathrm{H}_{f}\right] /[\mathrm{CO}]$ ratio. Only successful detonations are shown.

Figure 19: Mechanism validation for $\mathrm{CO}-\mathrm{H}_{2}-\mathrm{O}_{2}-\mathrm{Ar}$ mixtures. Shock tube data is for the mixture $0.049 \% \mathrm{H}_{2}, 1.01 \% \mathrm{O}_{2}, 3.28 \% \mathrm{CO}, \mathrm{Ar}$

Figure 20: Mechanism validation for $\mathrm{C}_{6} \mathrm{H}_{14}-\mathrm{O}_{2}$ - $\mathrm{Ar}$ mixtures. Circles and dashed lines correspond to data and calculations respectively for mixture A. Squares and solid lines correspond to data and calculations respectively for mixture B.

Figure 21: Mechanism validation for $\mathrm{C}_{2} \mathrm{H}_{2}-\mathrm{O}_{2}-\mathrm{Ar}$ mixtures. Circles and 
dashed lines correspond to $63 \% \mathrm{~N}_{2}$ dilution; squares and solid lines correspond to $74 \% \mathrm{~N}_{2}$ dilution. Both mixtures are stoichiometric at 4 bar postshock pressure.

Figure 22: Calculated species mole fractions through the reaction zone in stoichiometric $\mathrm{CO}-\mathrm{H}_{2}$-air mixtures. The unmarked line is temperature. $\mathrm{H}_{2}$ quantities are by fuel mole fraction. Note the differences in scale on the abscissa.

Figure 23: Magnitude of the peak $\mathrm{OH}$ mole fraction as a function of $\left[\mathrm{H}_{f}\right] /[\mathrm{CO}]$ ratio.

Figure 24: Calculated species mole fractions through the reaction zone in stoichiometric $\mathrm{CO}-\mathrm{C}_{6} \mathrm{H}_{14}$-air. Note the differences in scale on the abscissa.

Figure 25: Correlation of peak $\mathrm{OH}$ mole fraction location with the $\left[\mathrm{H}_{f}\right] /[\mathrm{CO}]$ ratio. Species concentrations are calculated by a ZND code.

Figure 26: Cell width measurements versus reaction zone thickness in CO$\mathrm{O}_{2}$ mixtures with hydrogen/ hydrocarbon additive at $100 \mathrm{kPa}$. The reaction zone thickness is defined by a) the location of the maximum temperature gradient or b) by the location of the $\mathrm{OH}$ peak. 


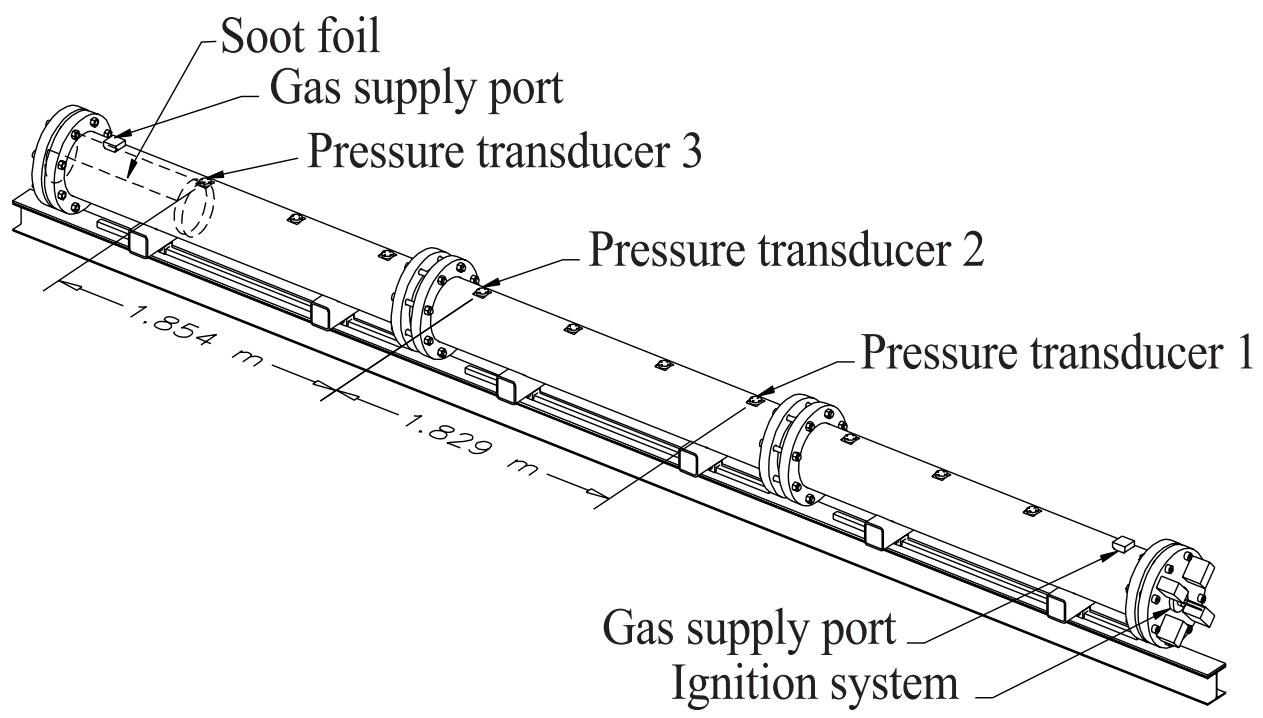

Figure 1: 


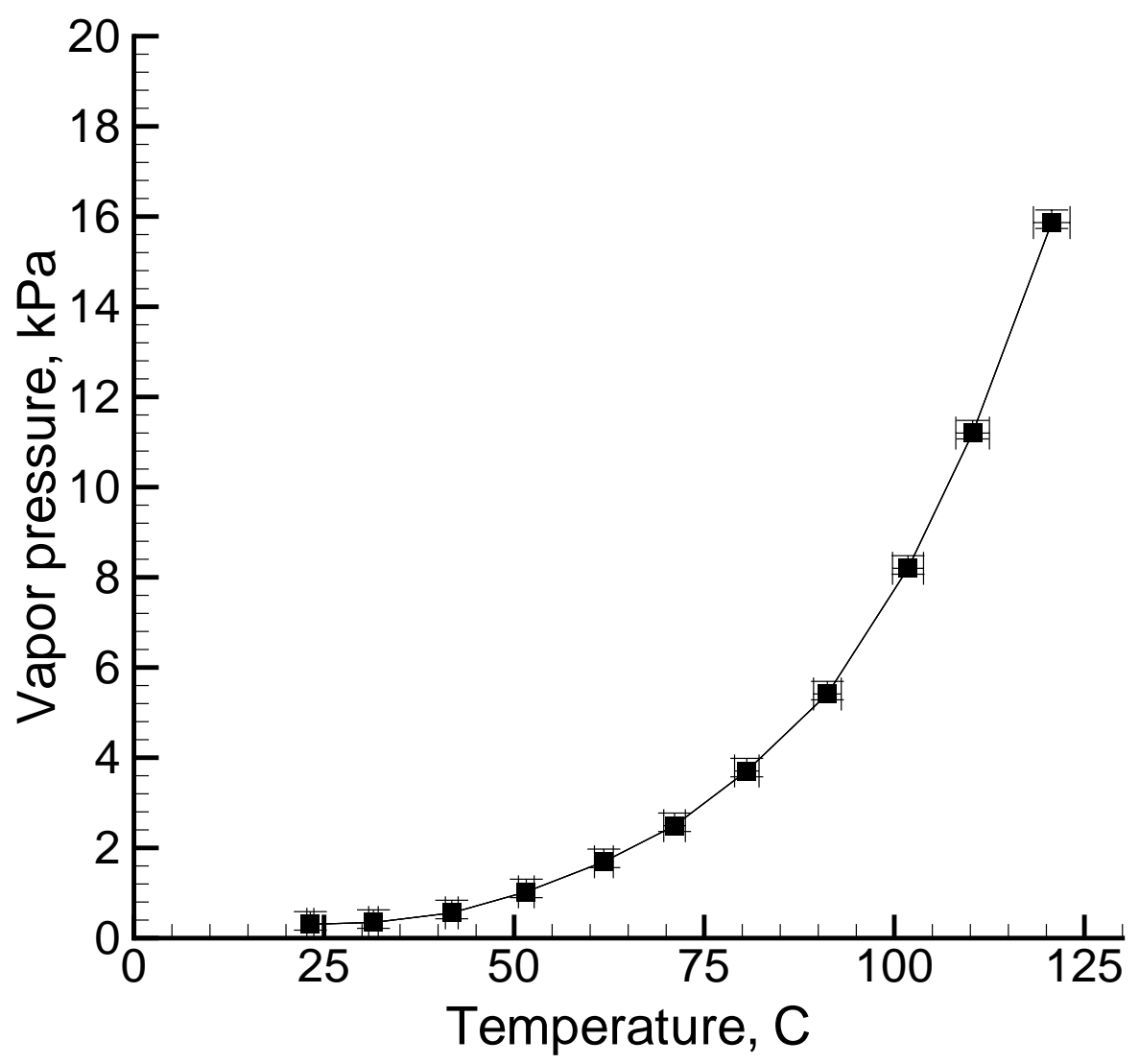

Figure 2: 

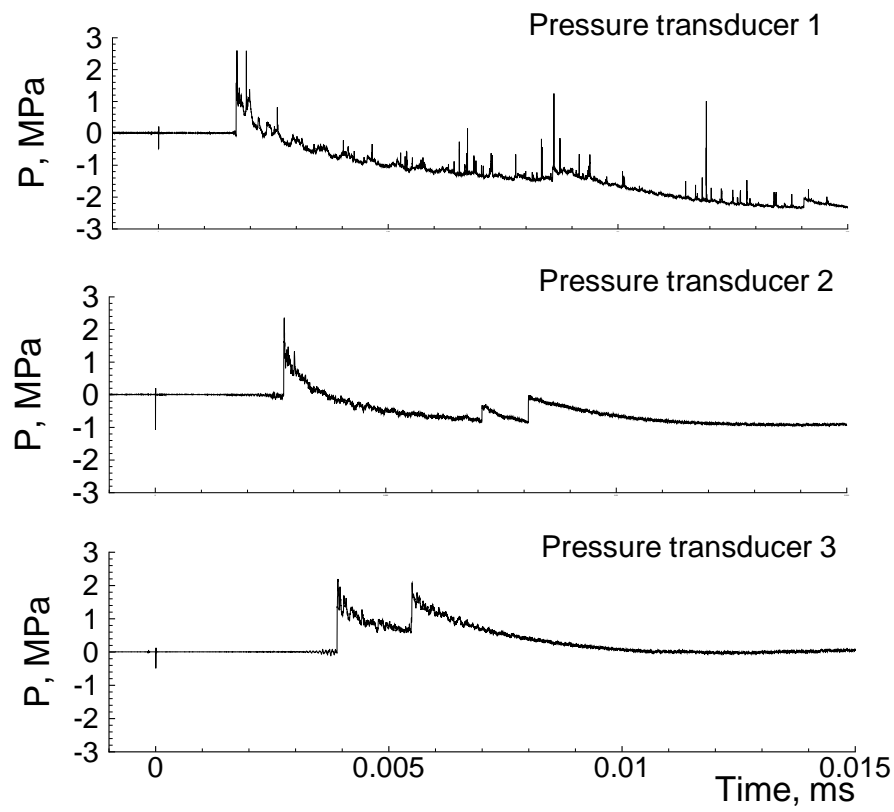

(a)
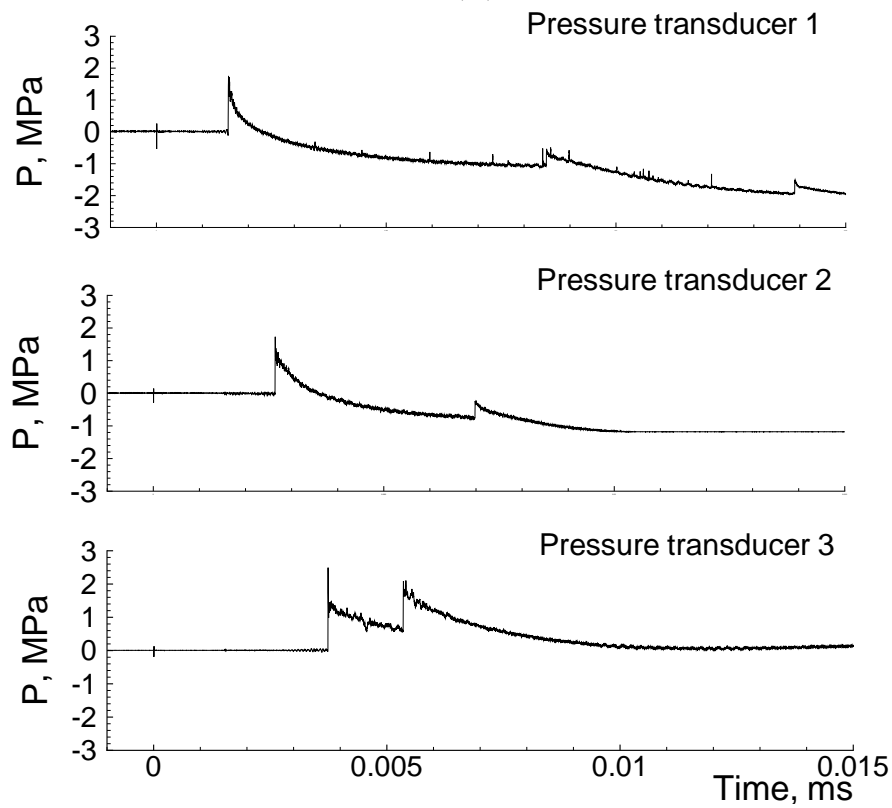

(b)

Figure 3: 


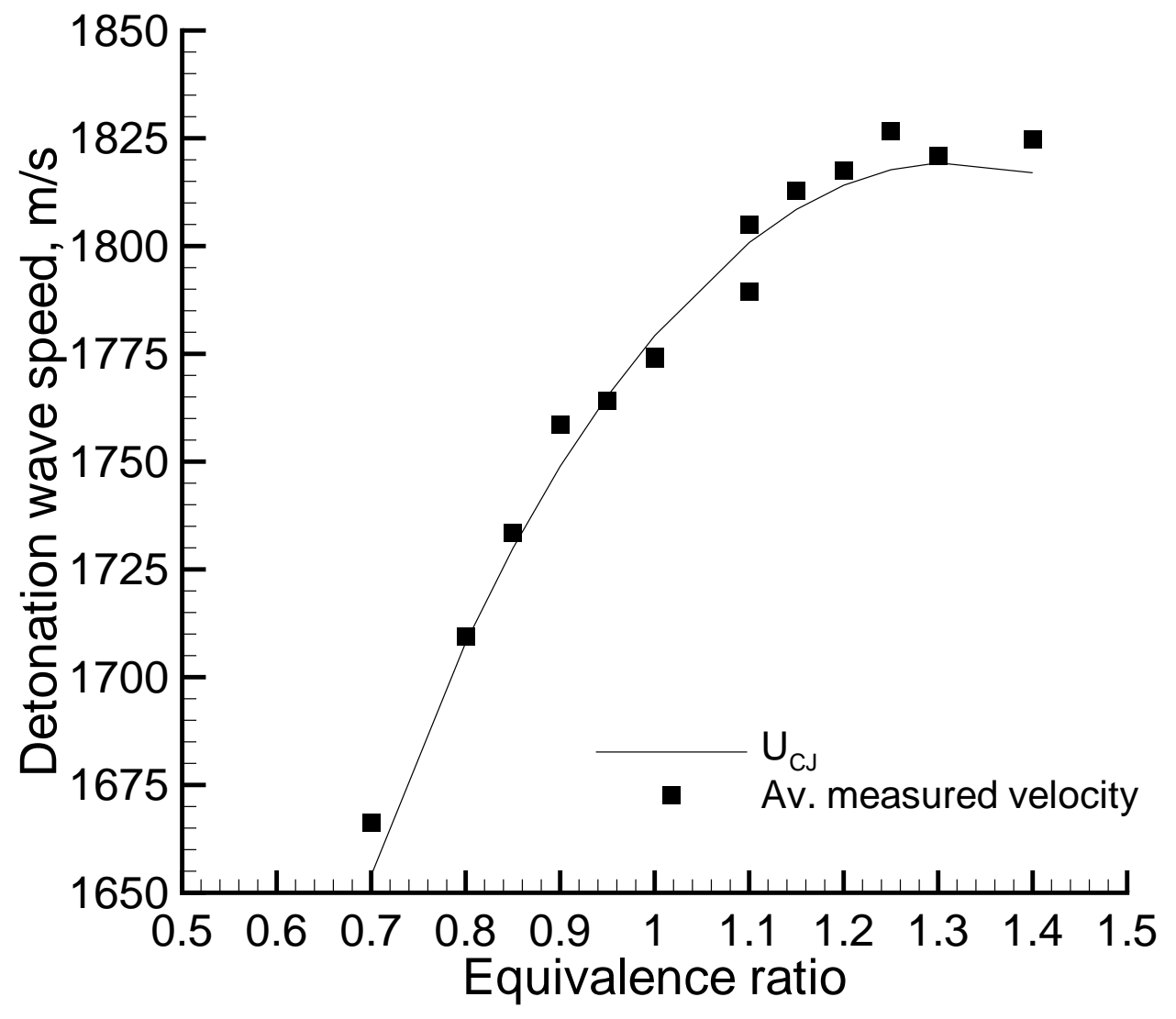

Figure 4: 


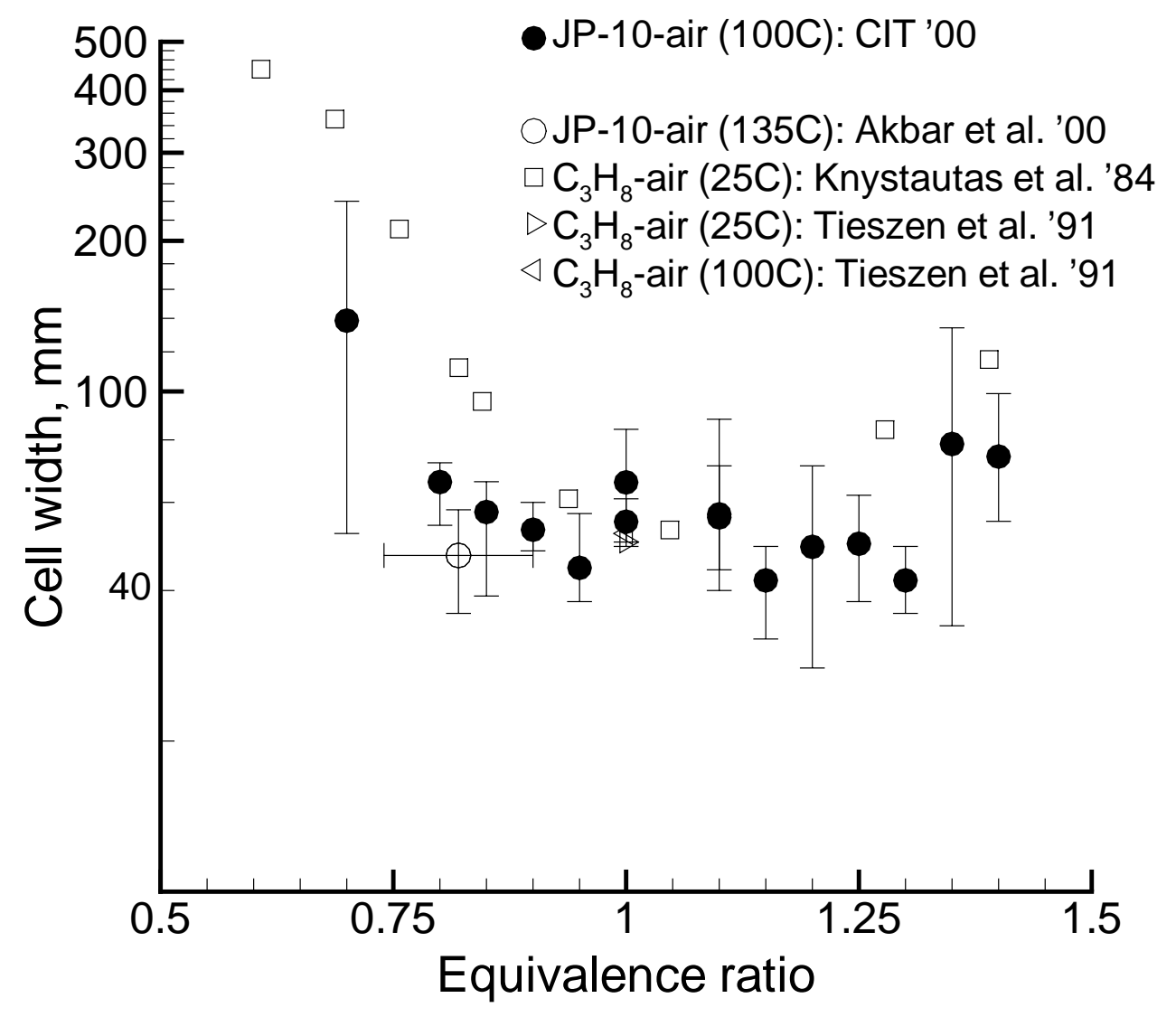

Figure 5: 


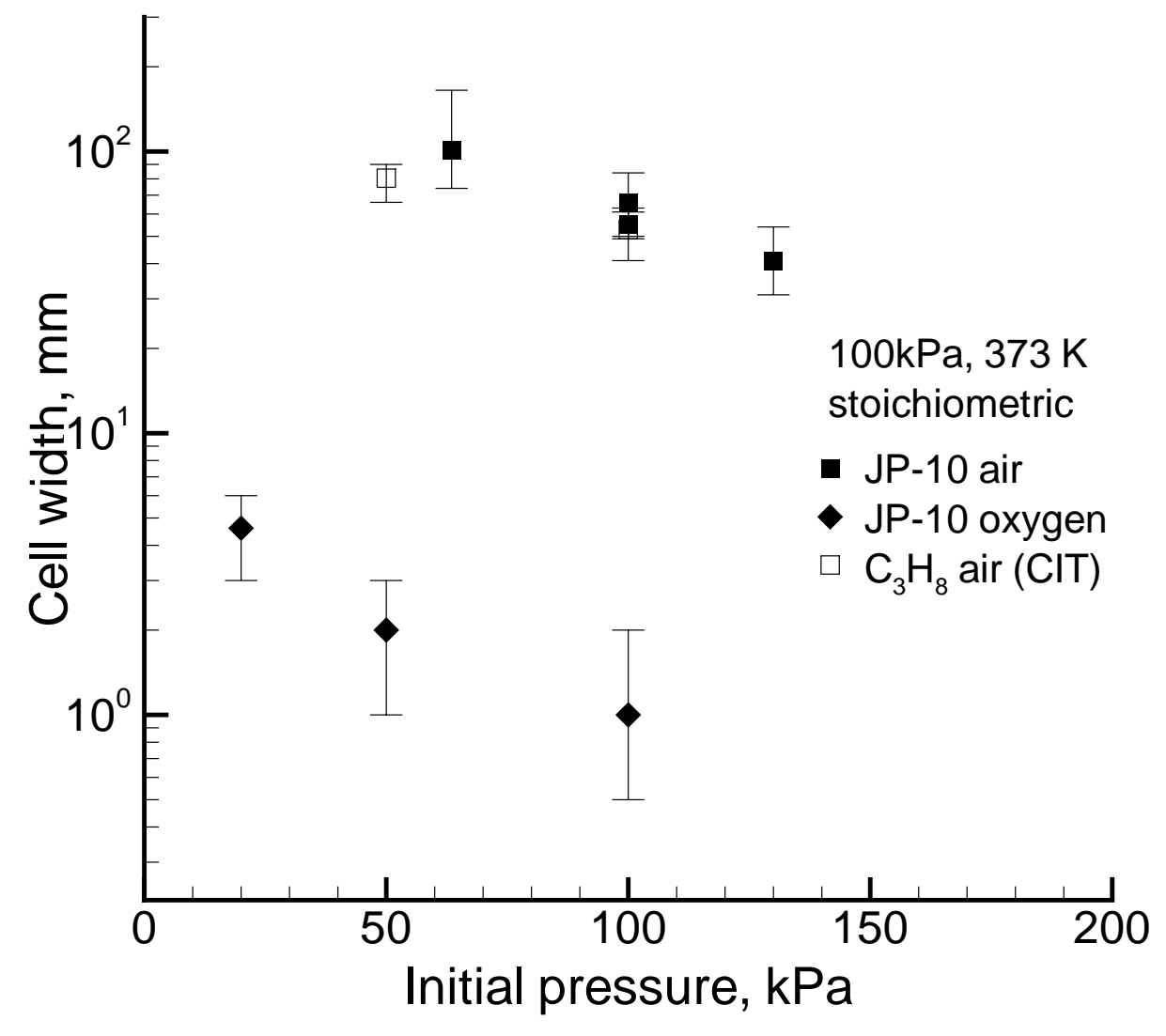

Figure 6: 


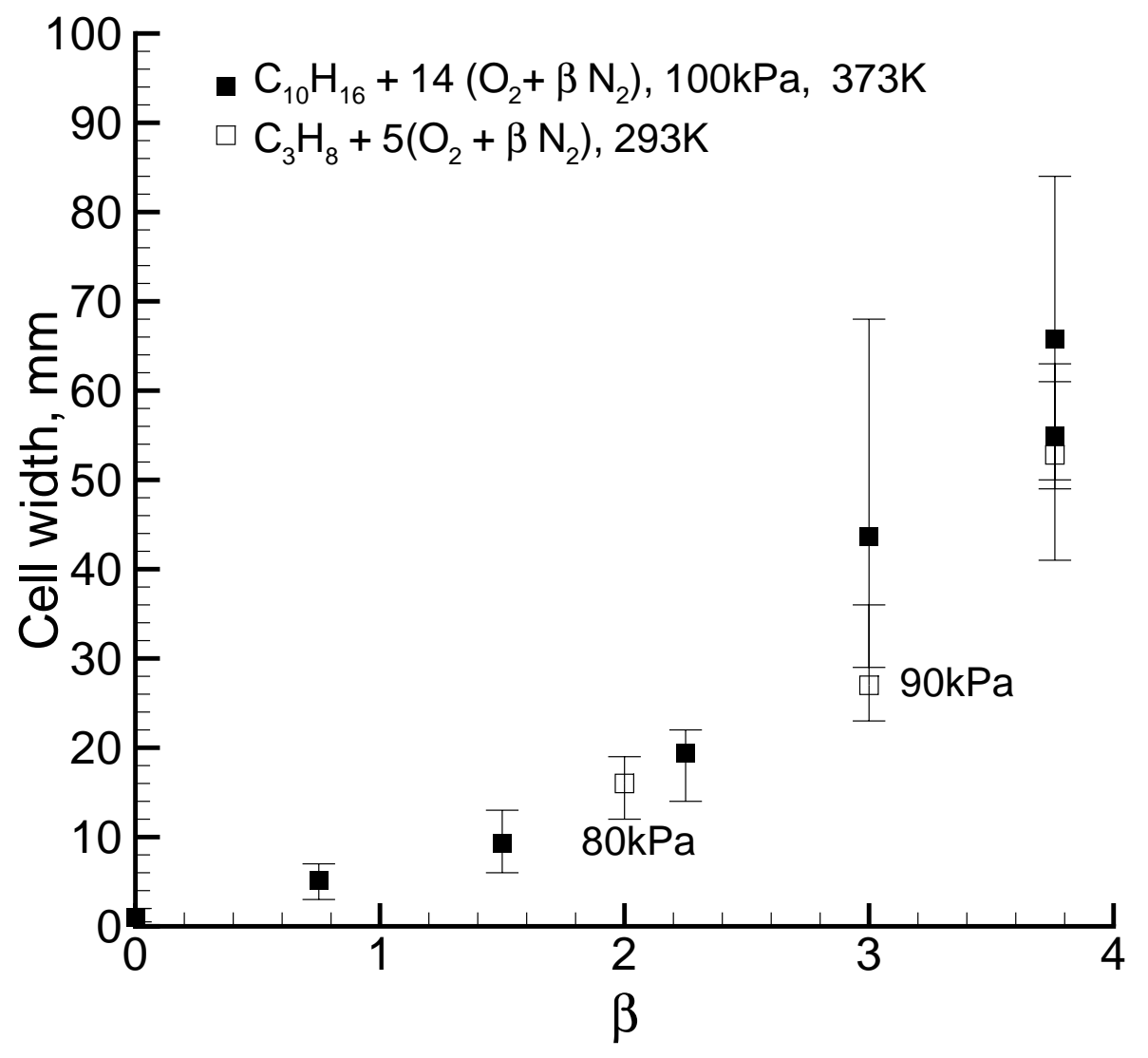

Figure 7: 


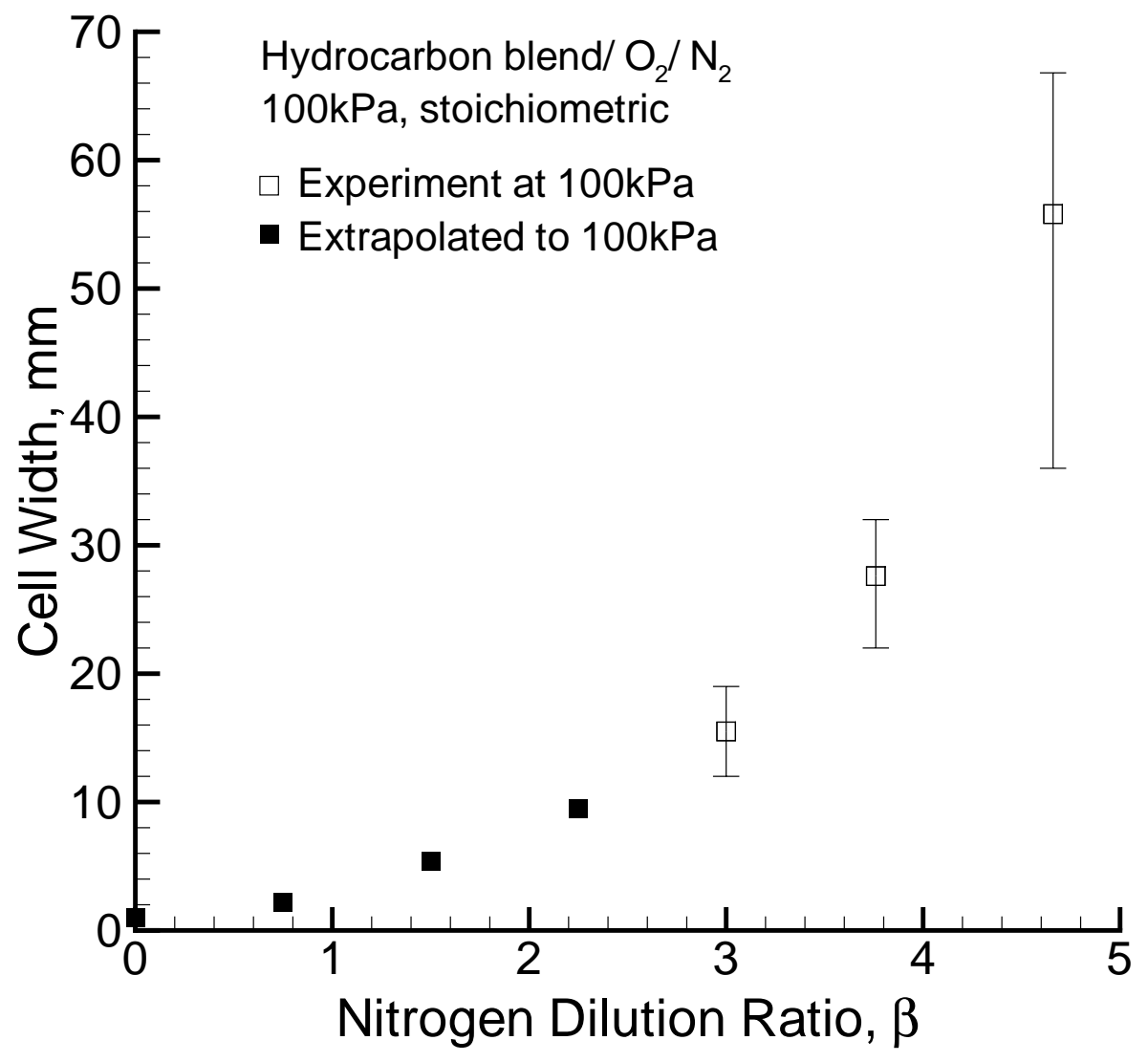

Figure 8: 


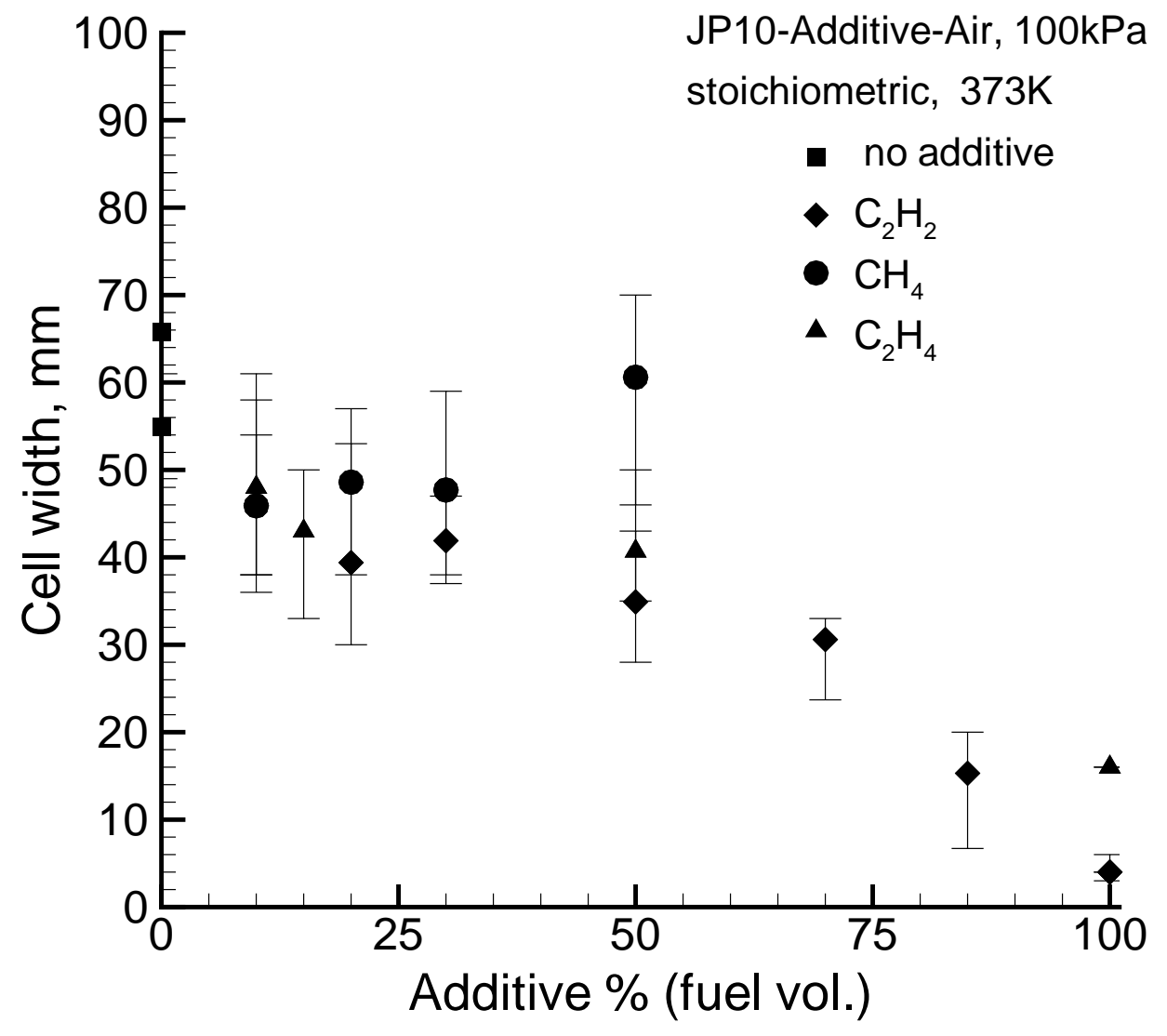

Figure 9: 


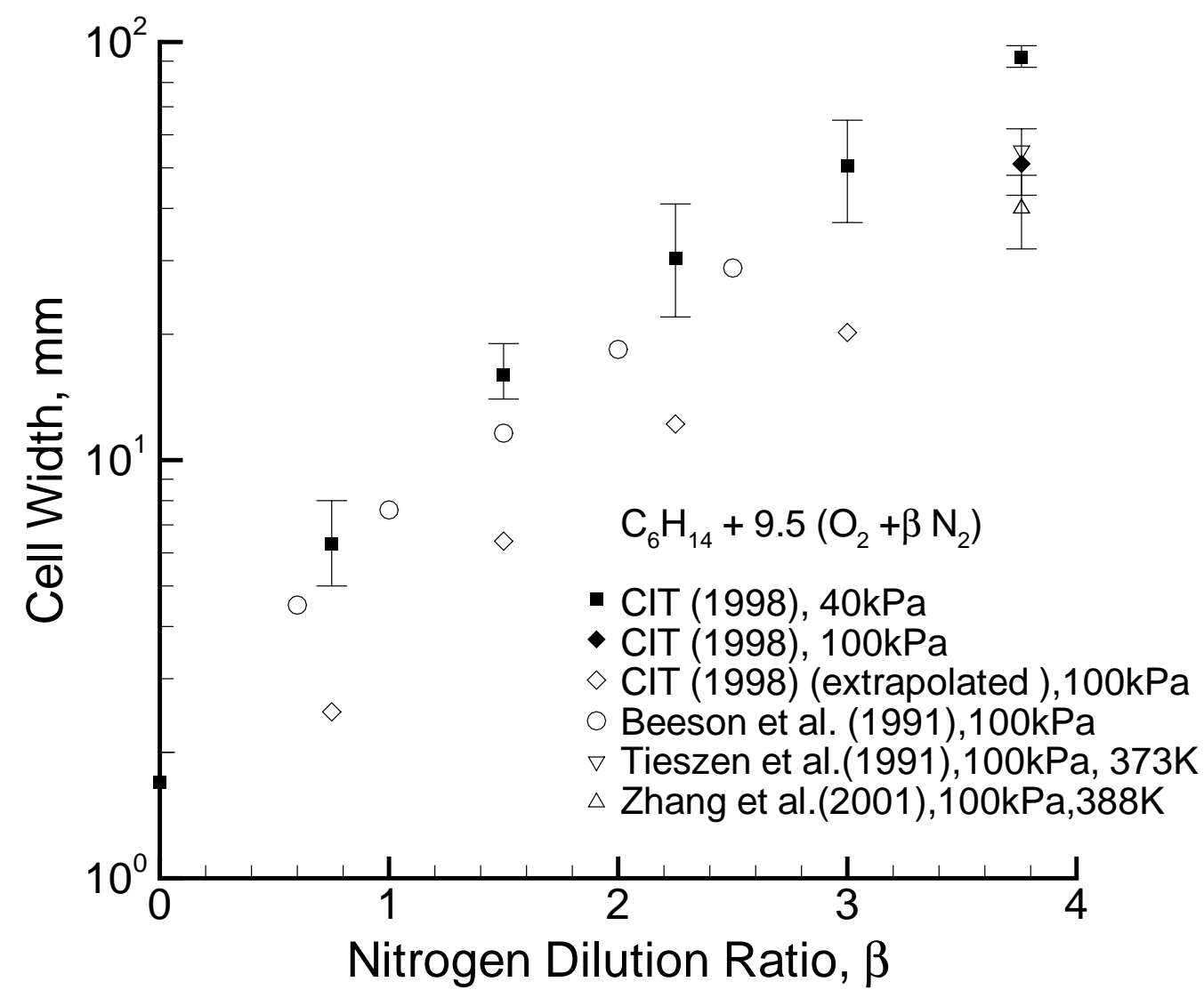

Figure 10: 


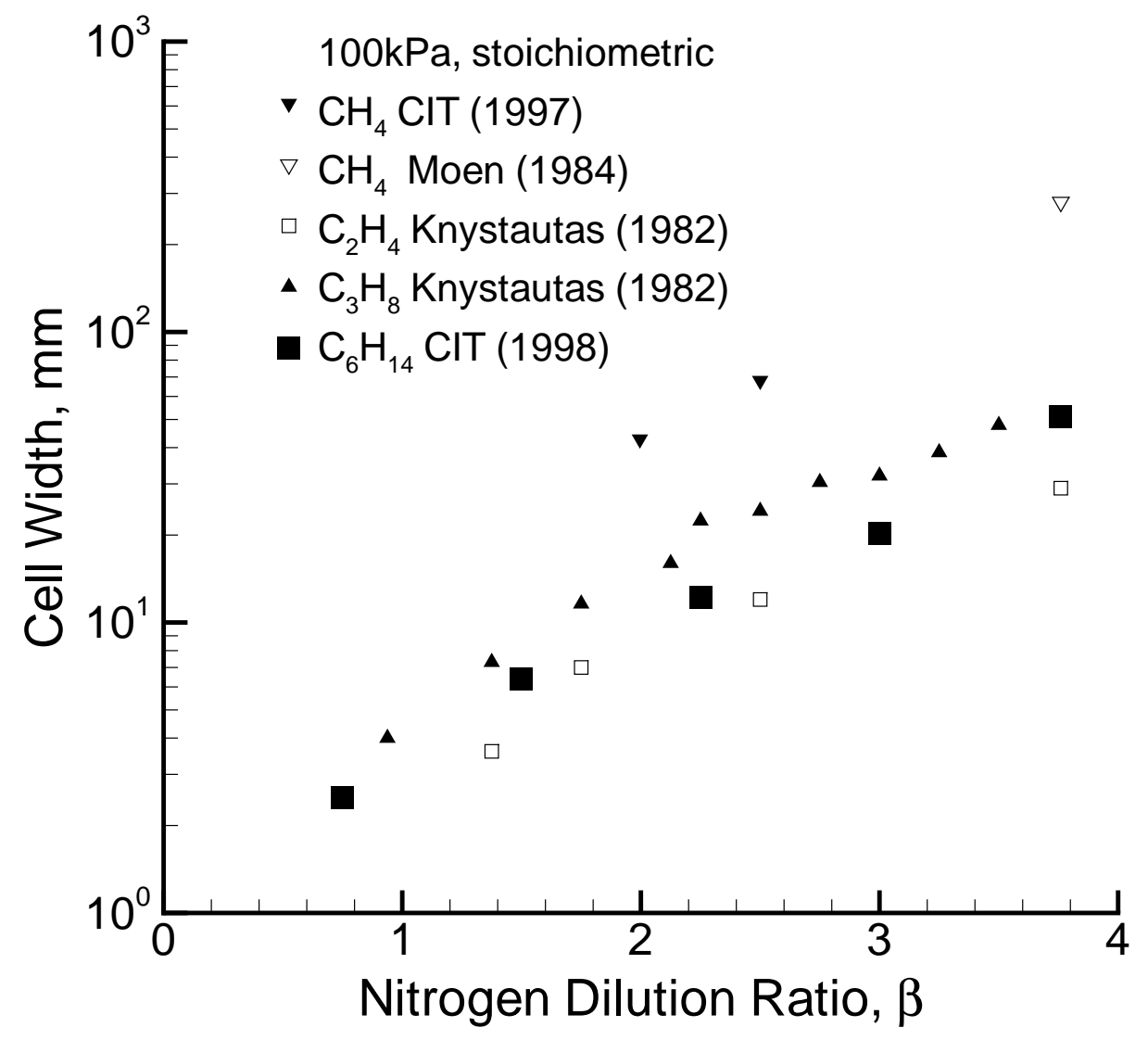

Figure 11: 


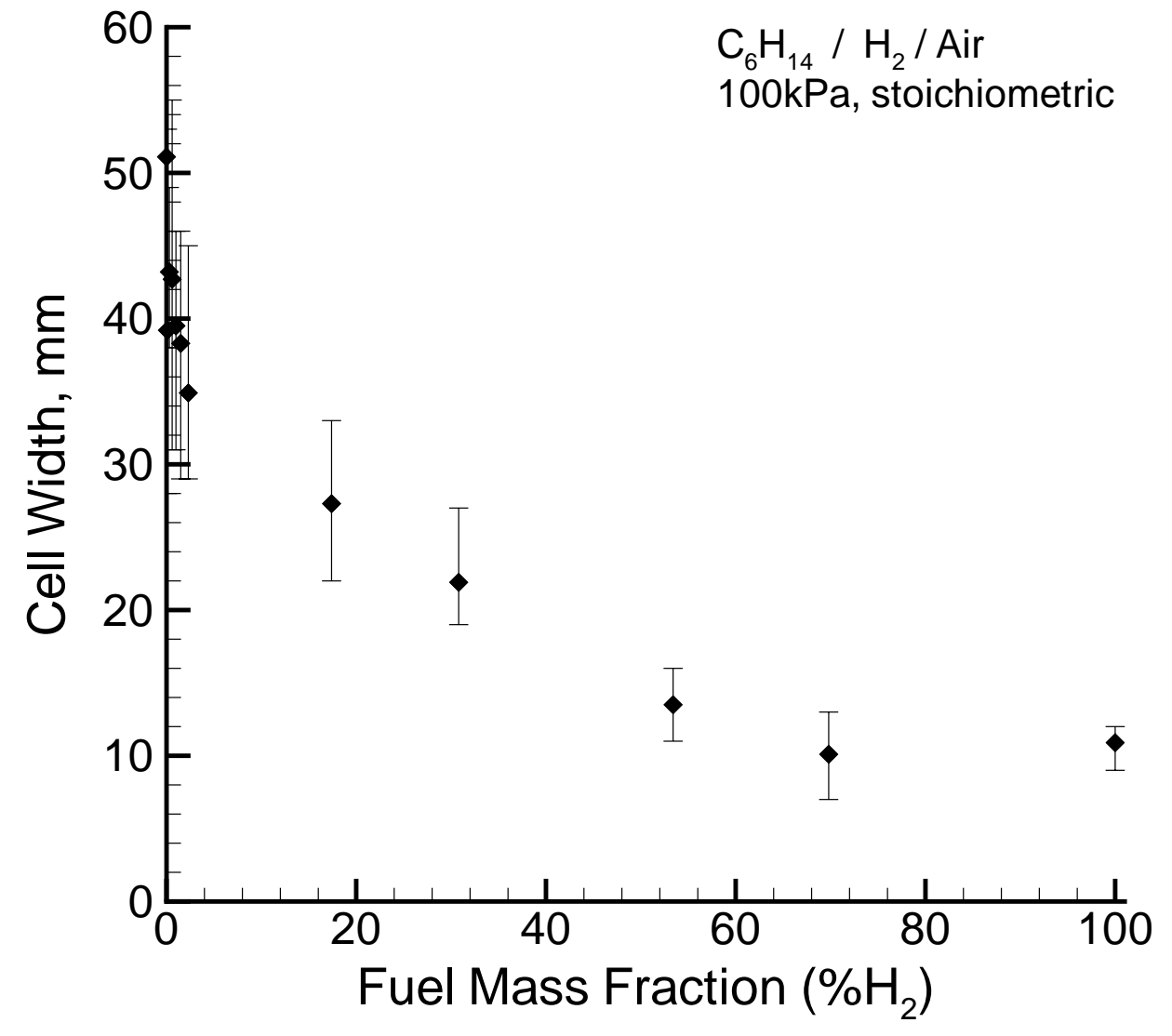

Figure 12: 


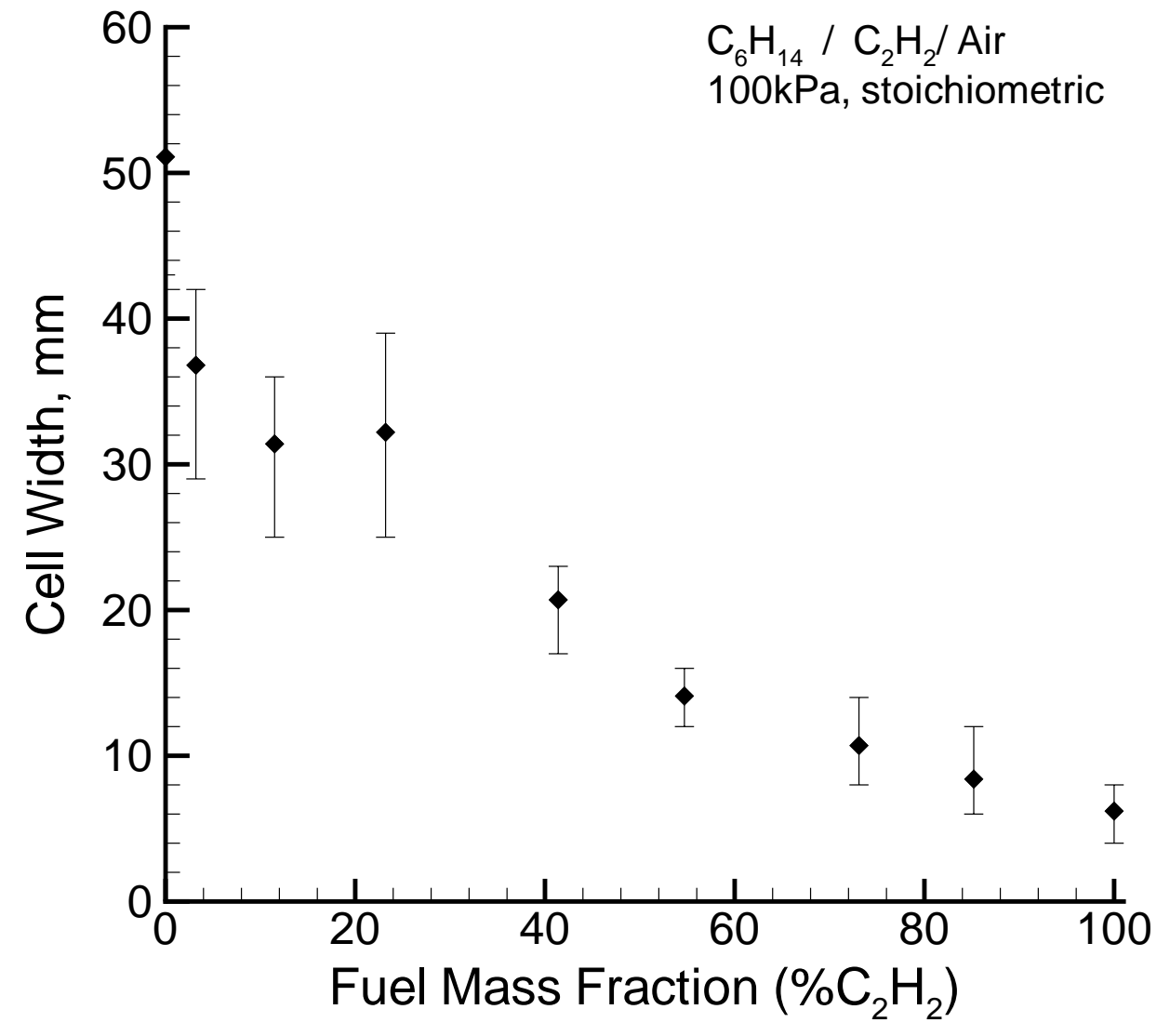

Figure 13: 


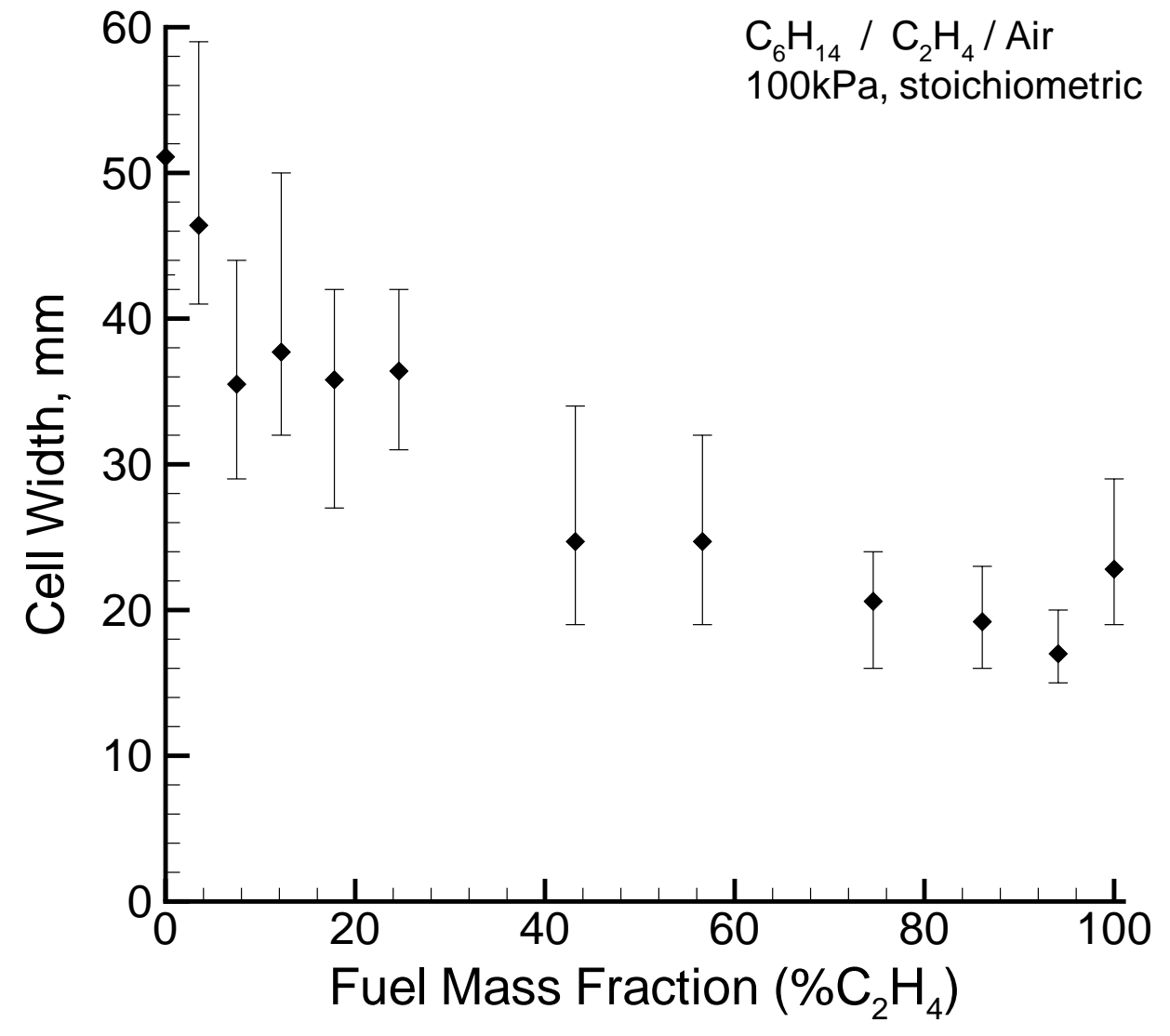

Figure 14: 


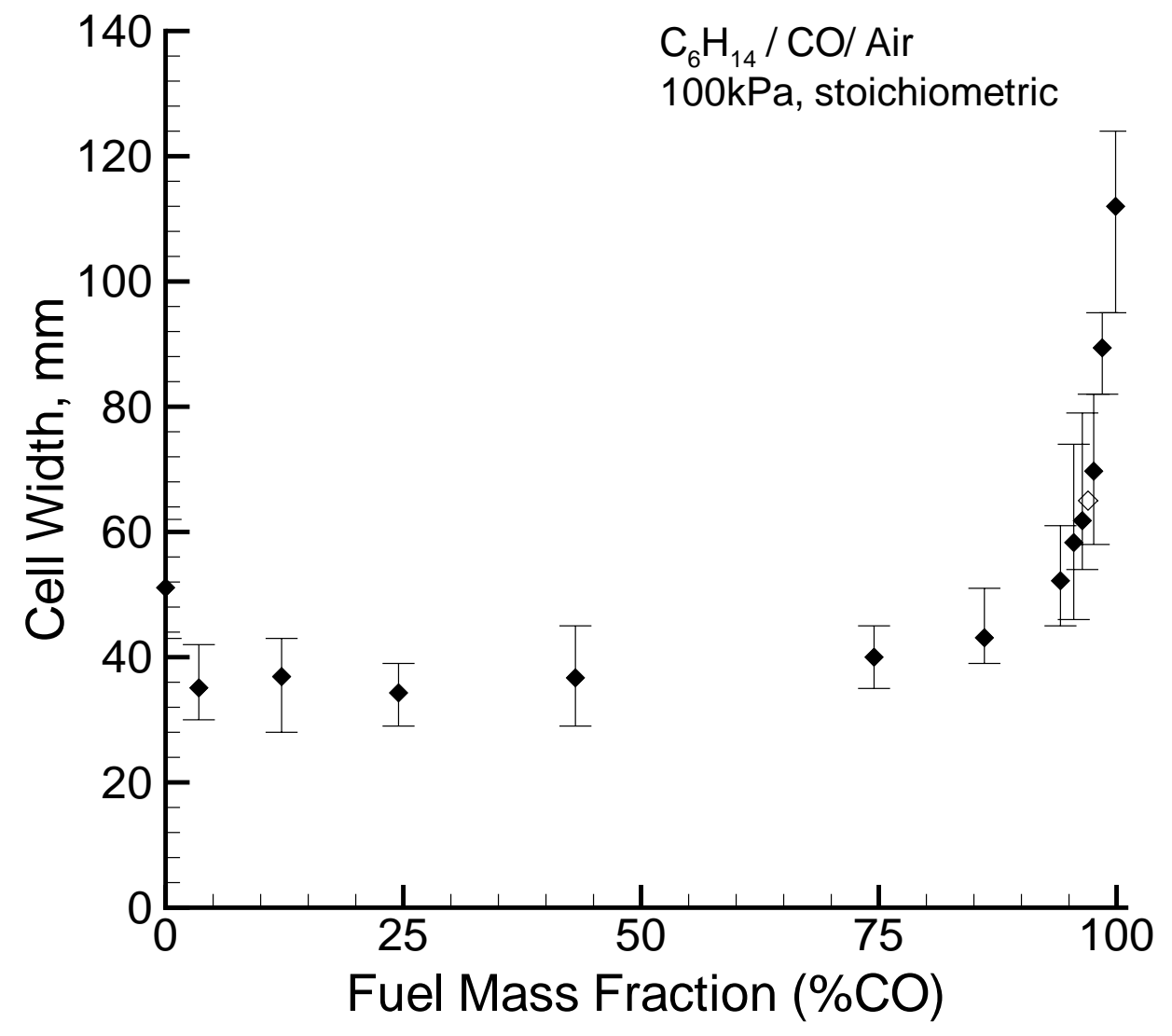

Figure 15: 


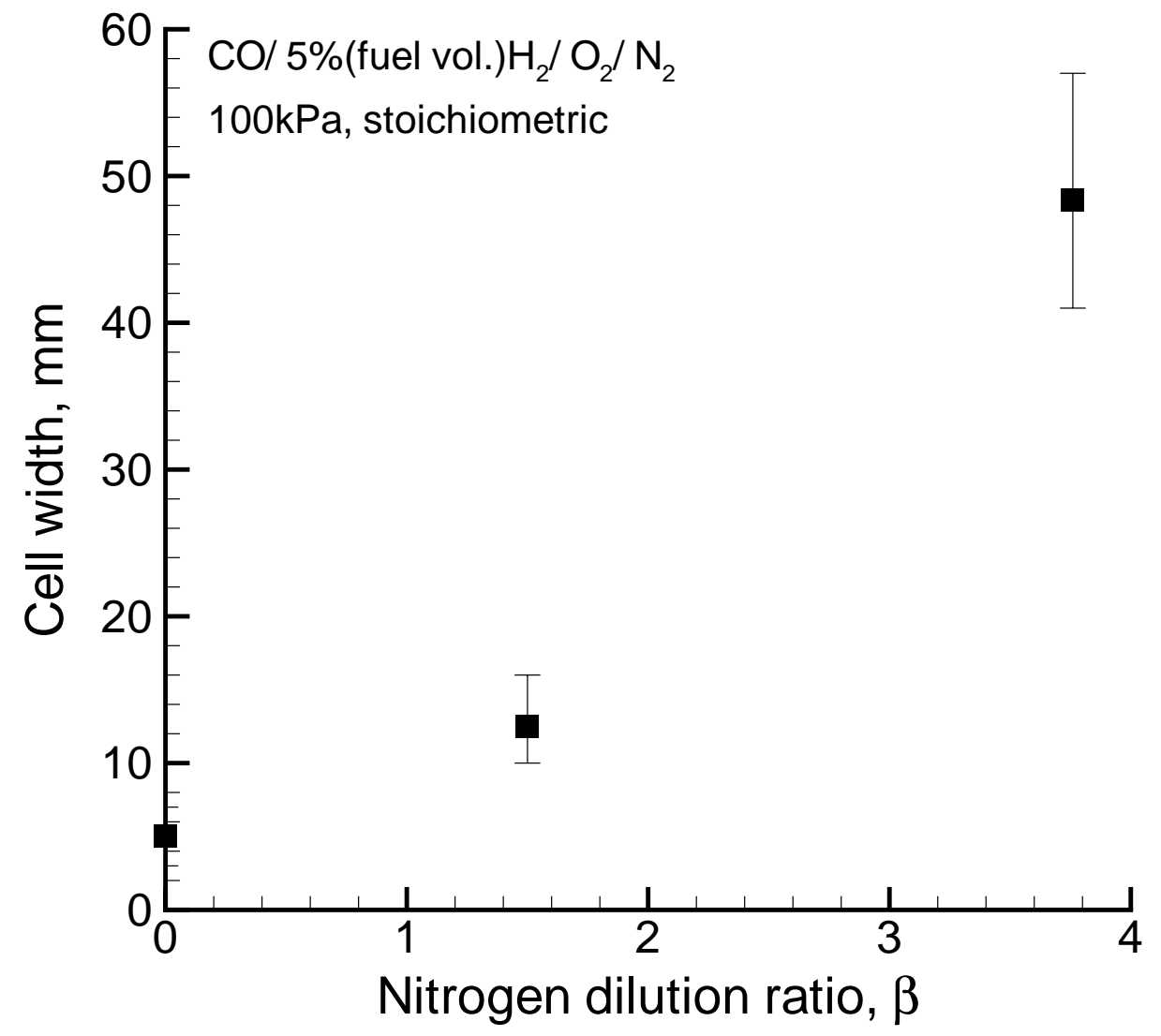

Figure 16: 


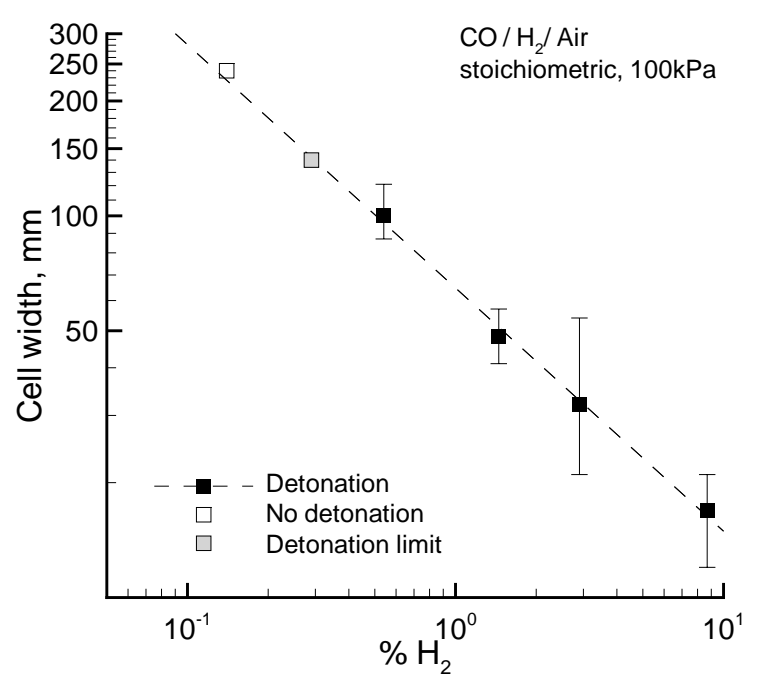

(a)

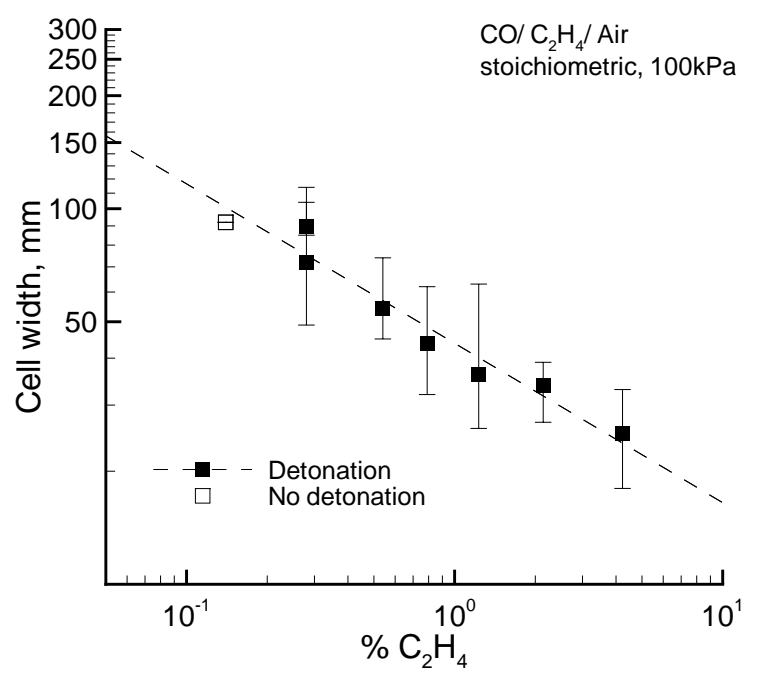

(c)

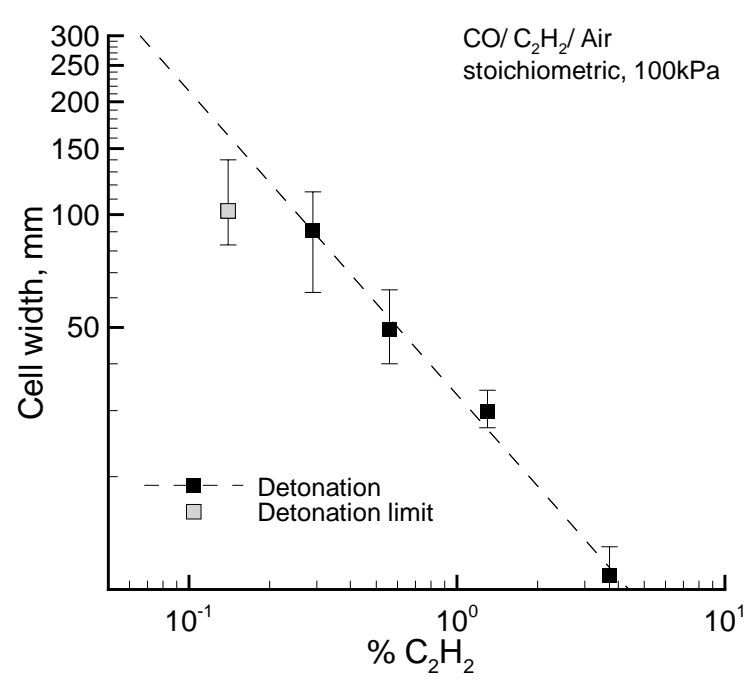

(b)

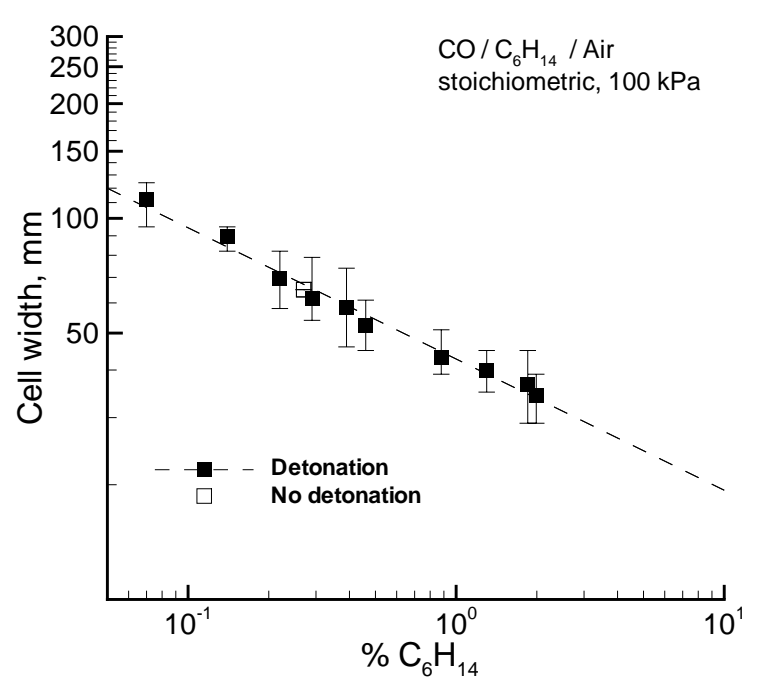

(d)

Figure 17: 


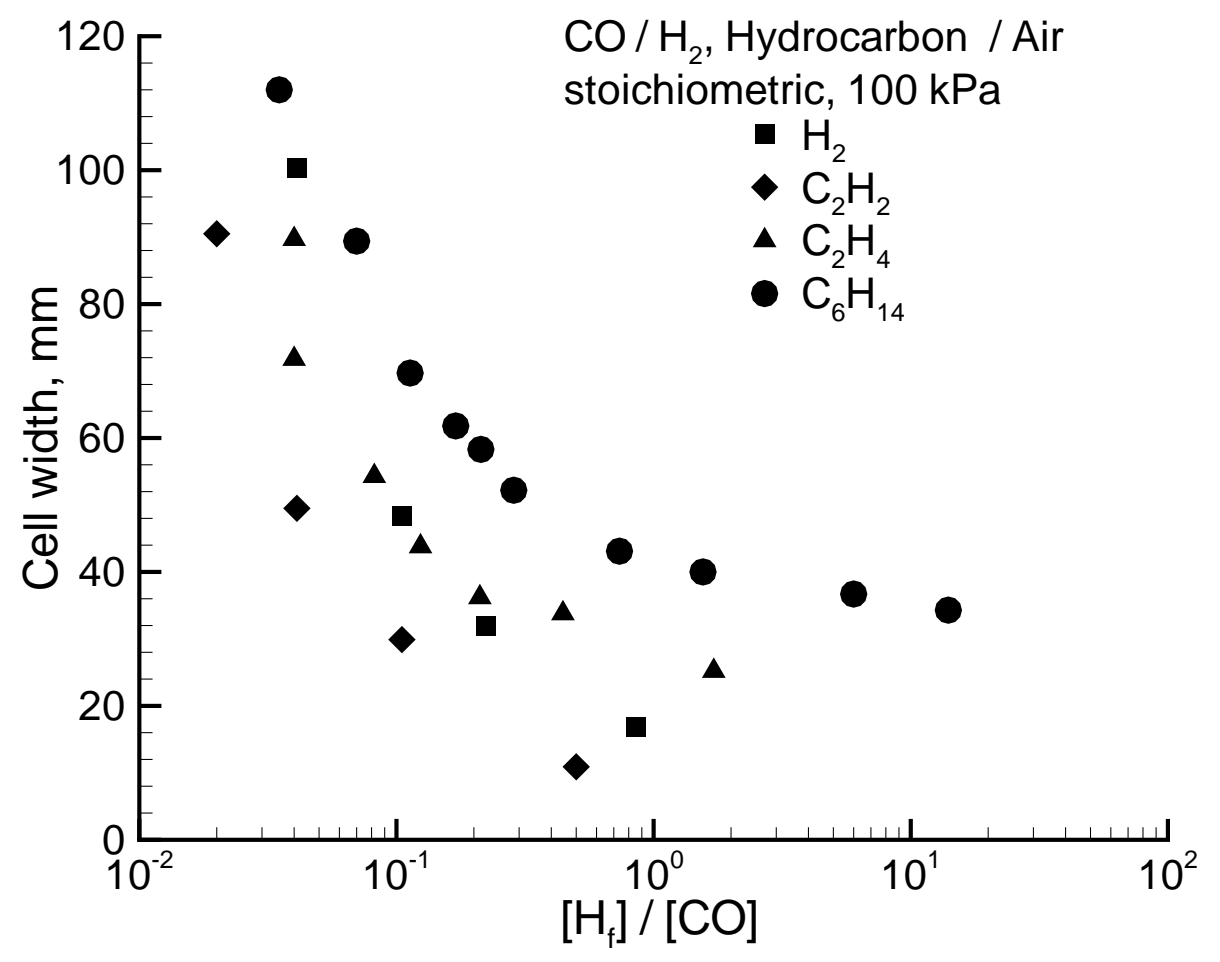

Figure 18: 


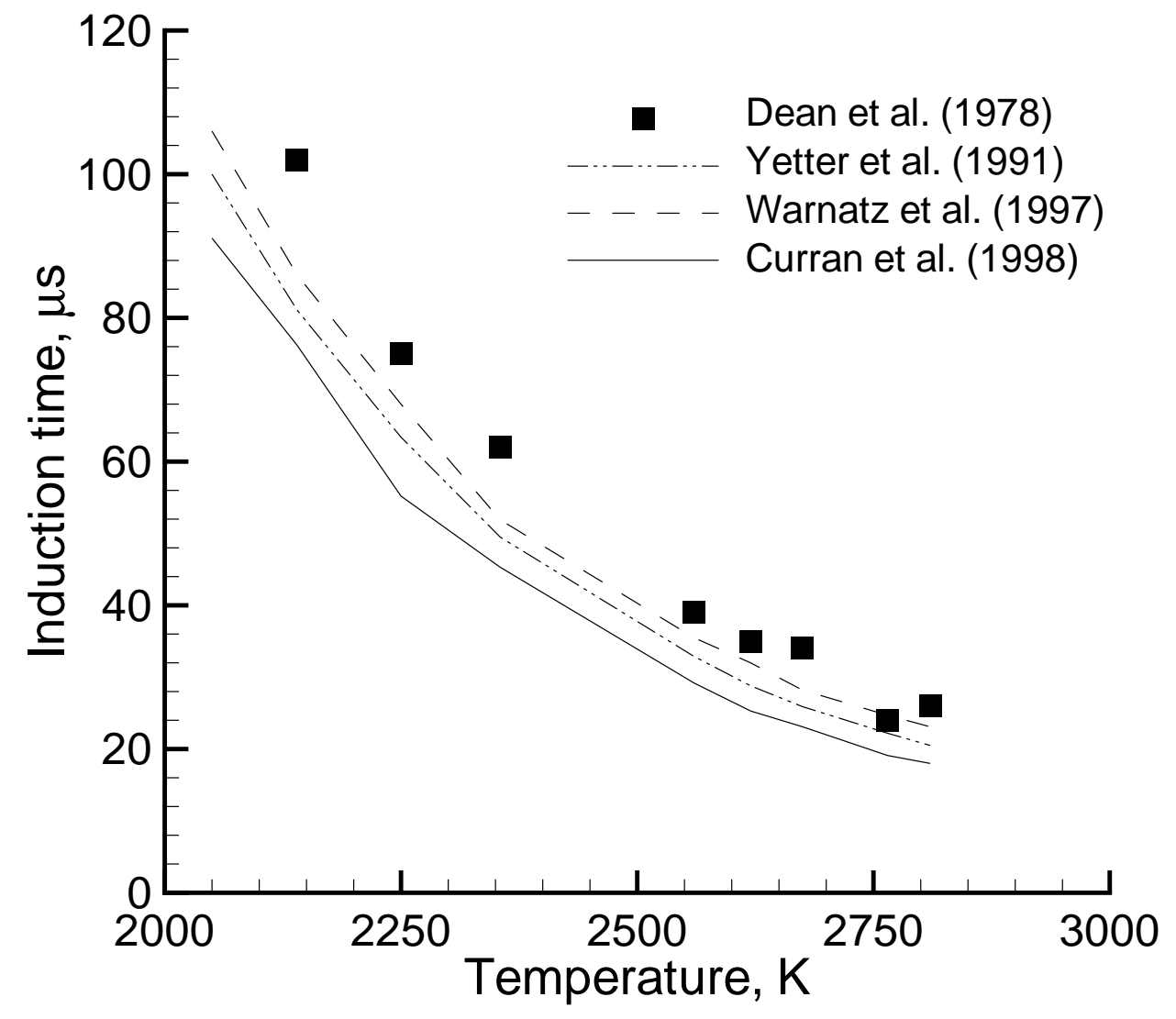

Figure 19: 


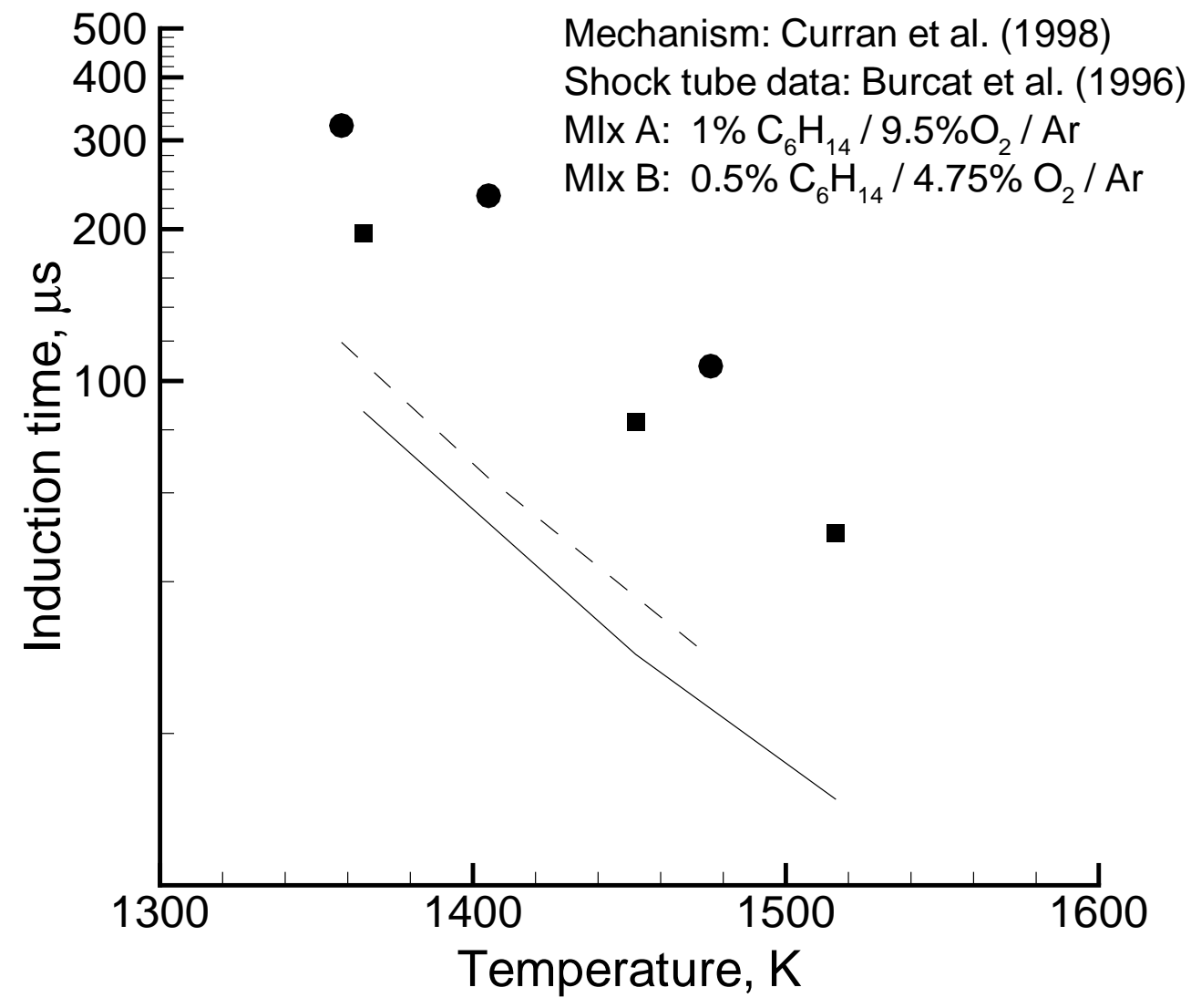

Figure 20: 


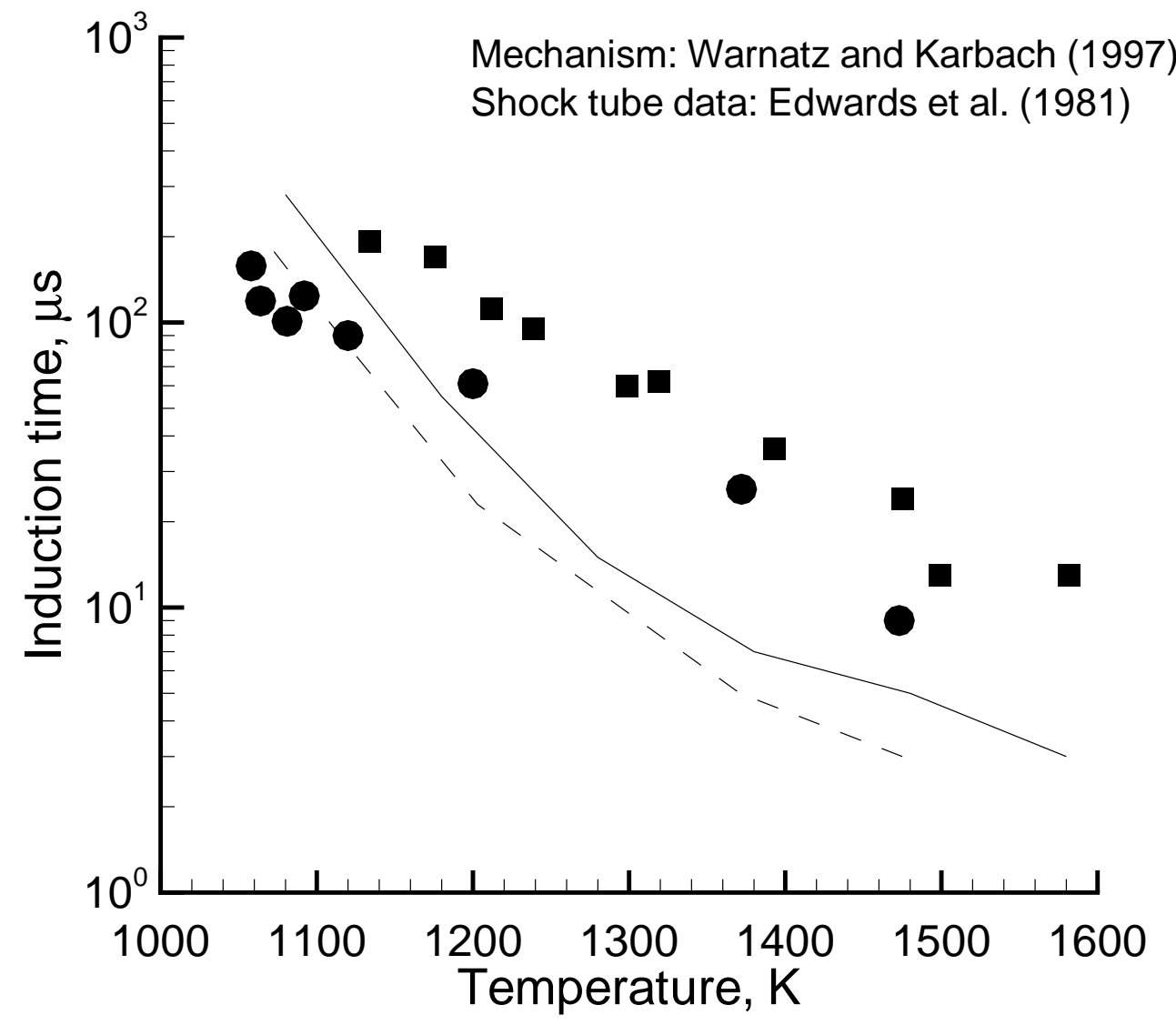

Figure 21: 


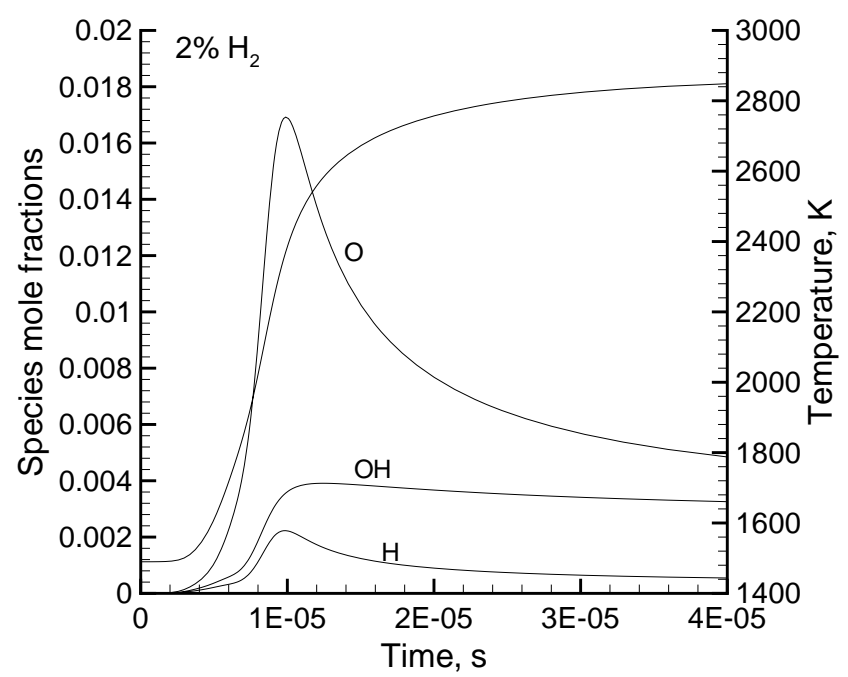

(a)

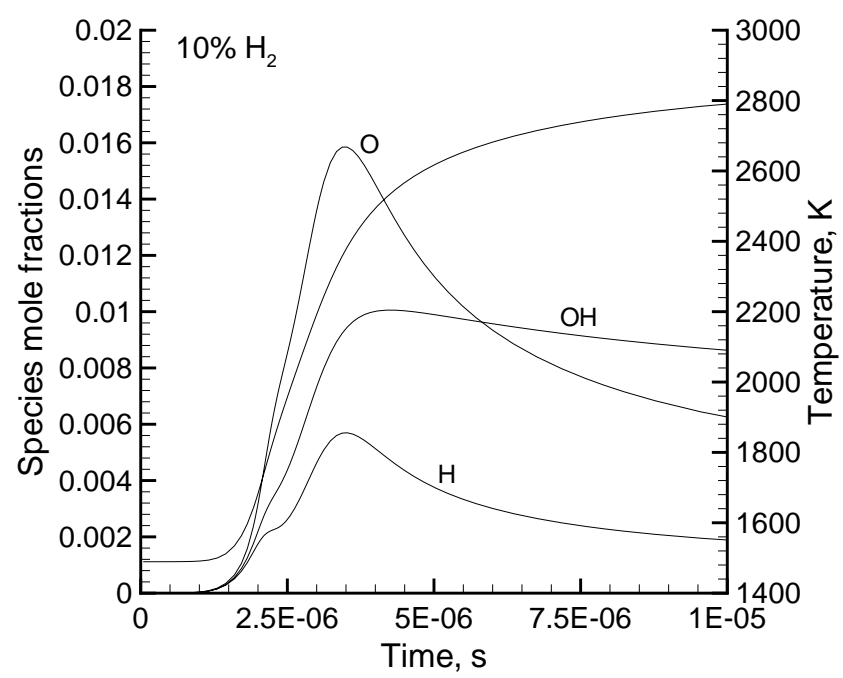

(c)

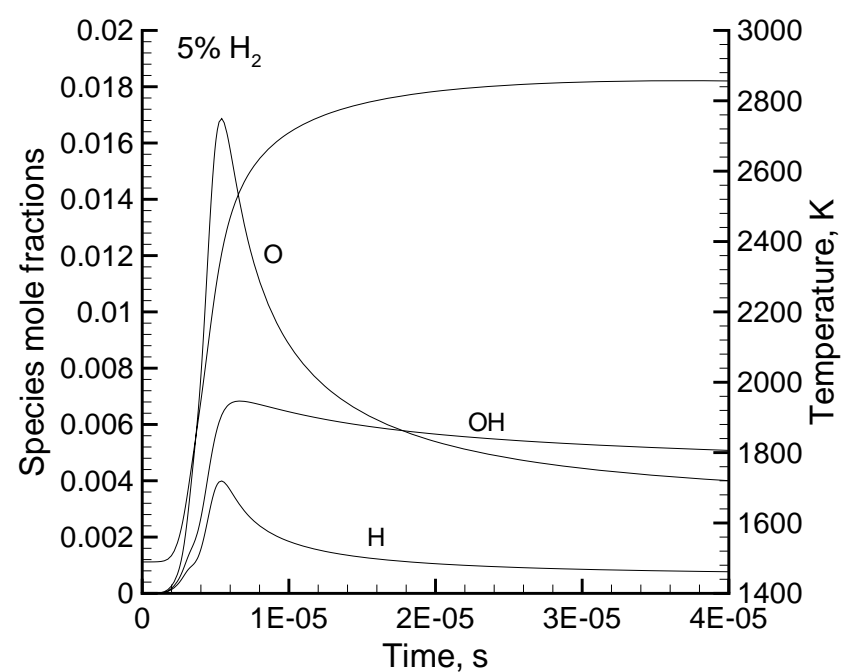

(b)

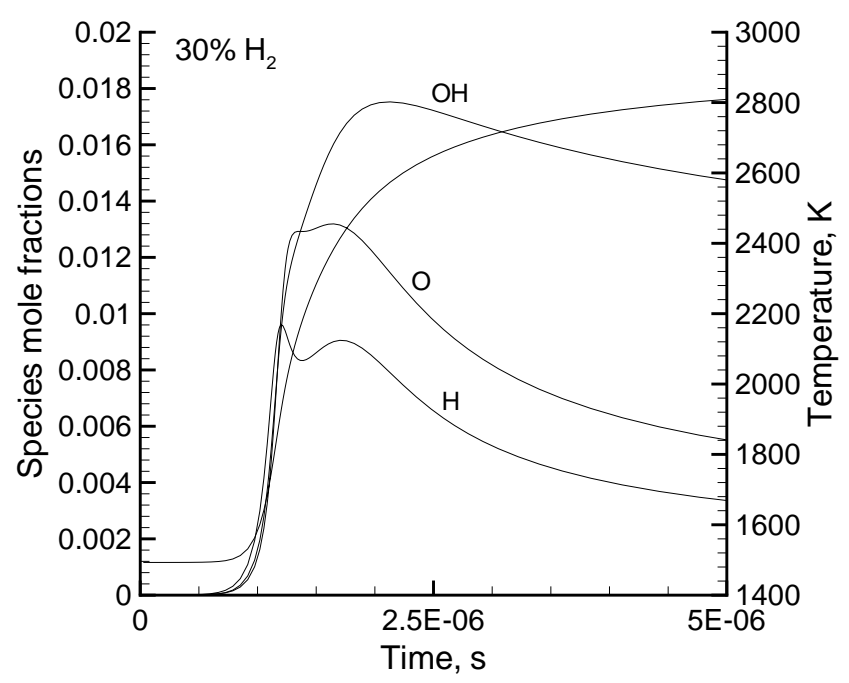

(d)

Figure 22: 


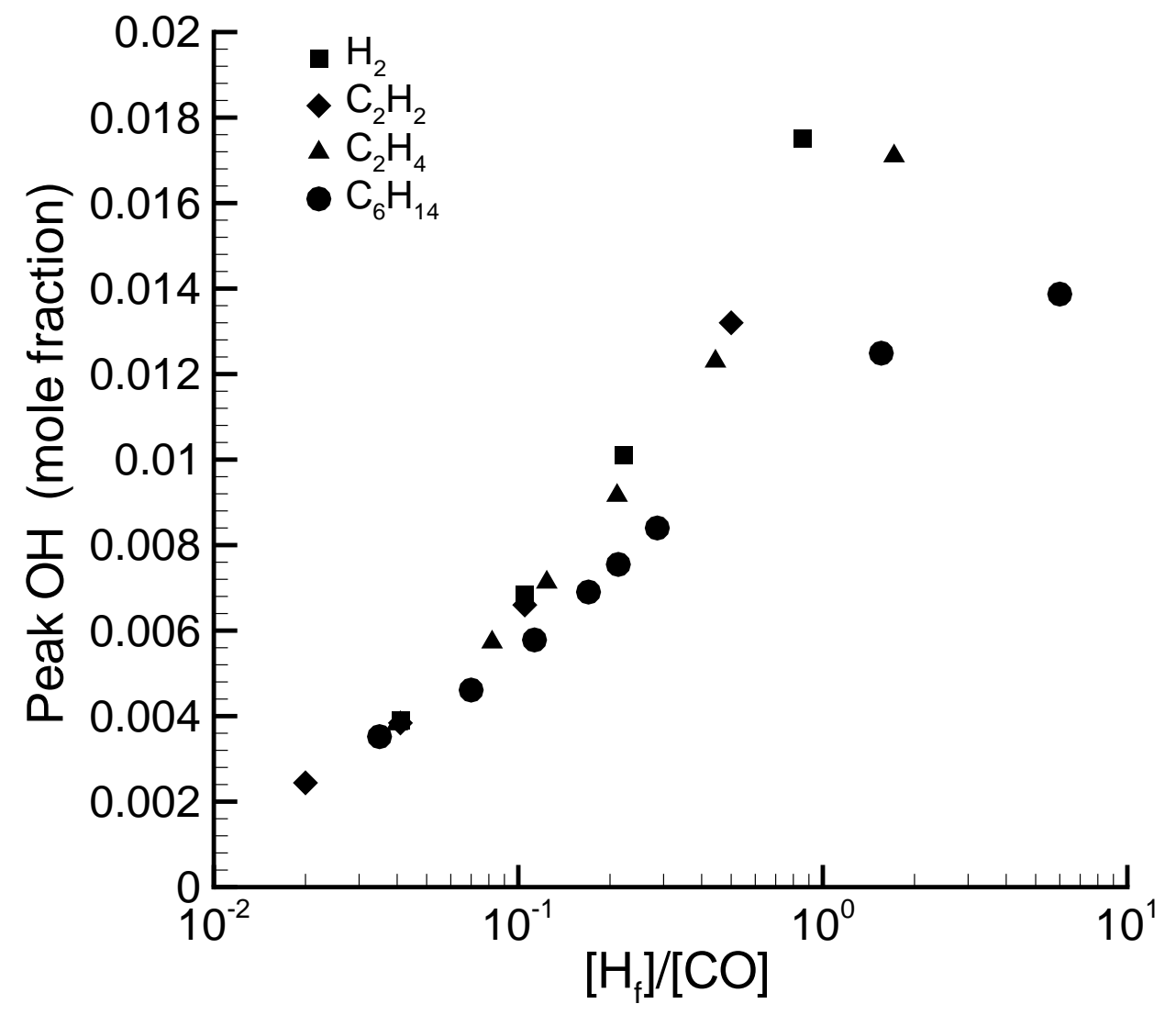

Figure 23: 


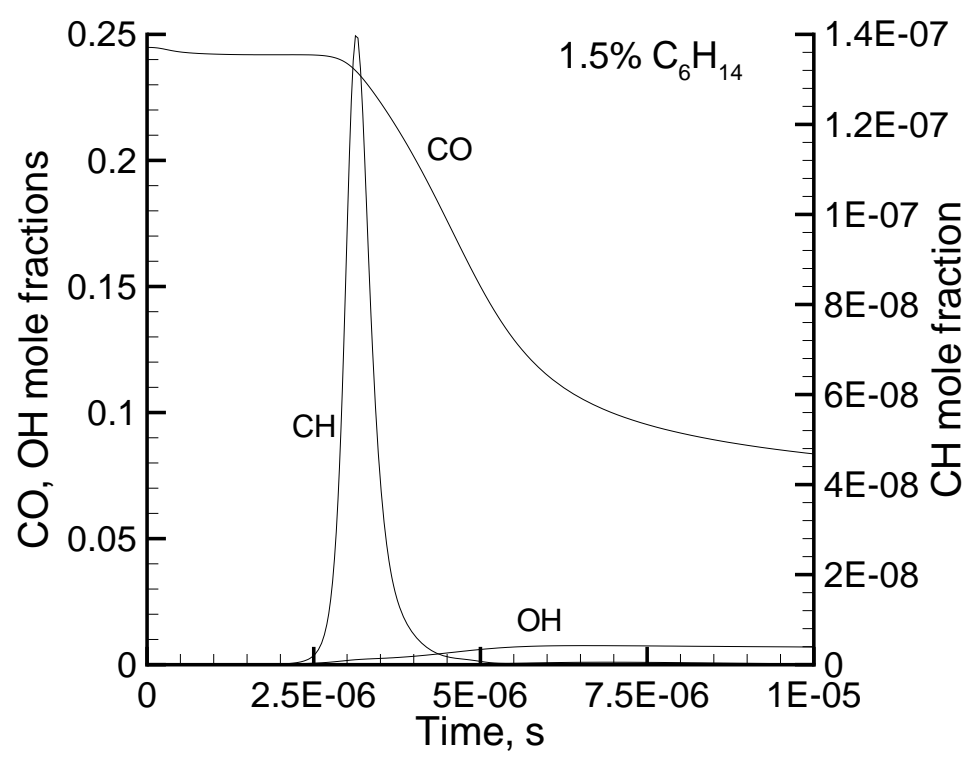

(a)

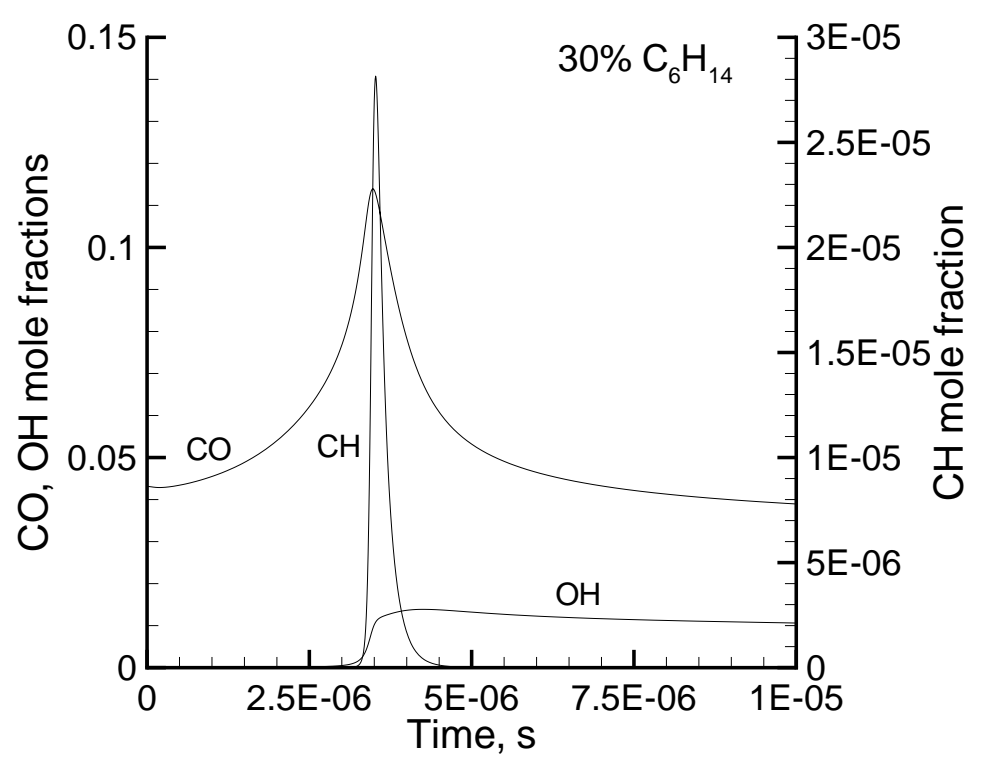

(b)

Figure 24: 


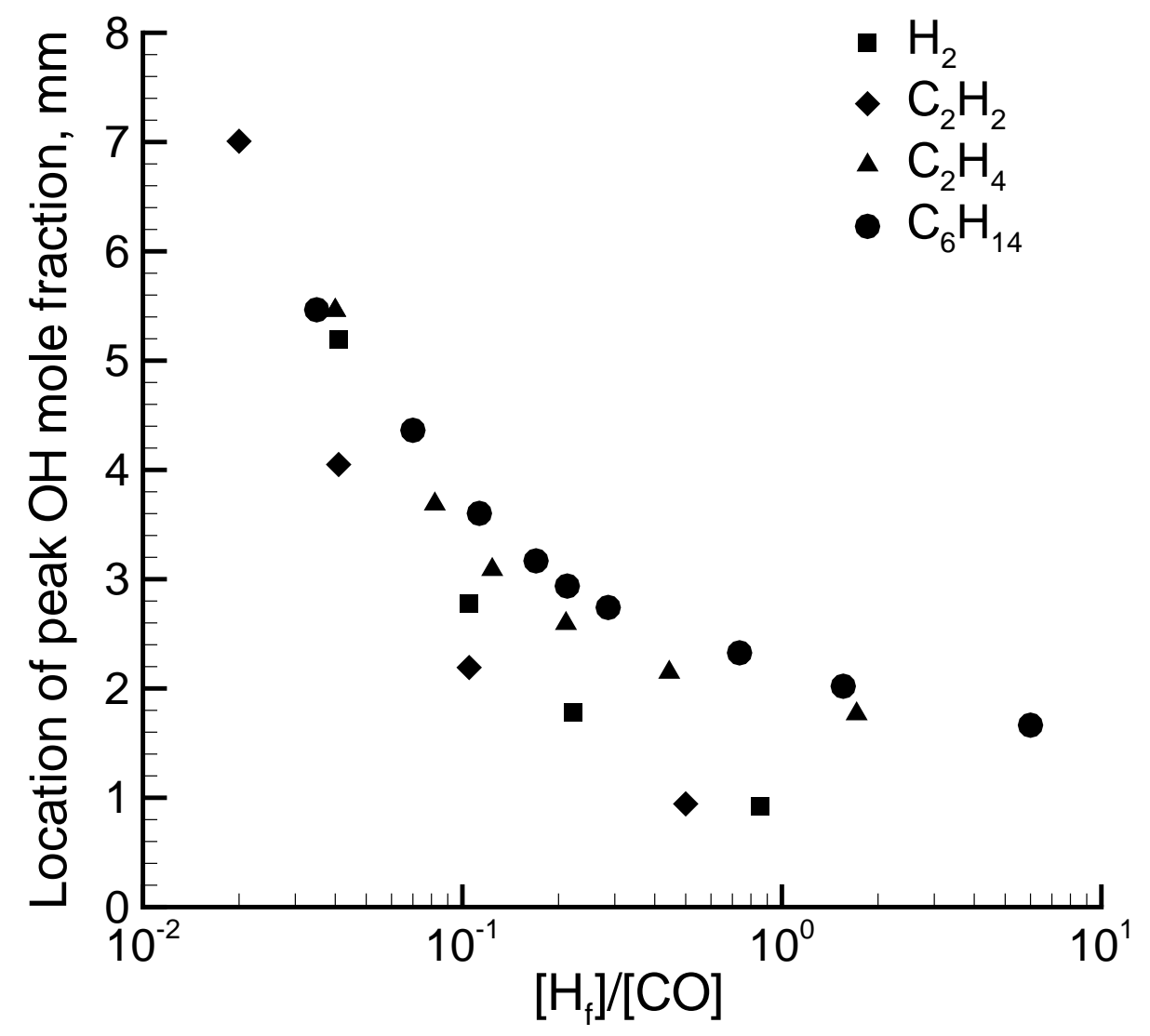

Figure 25: 


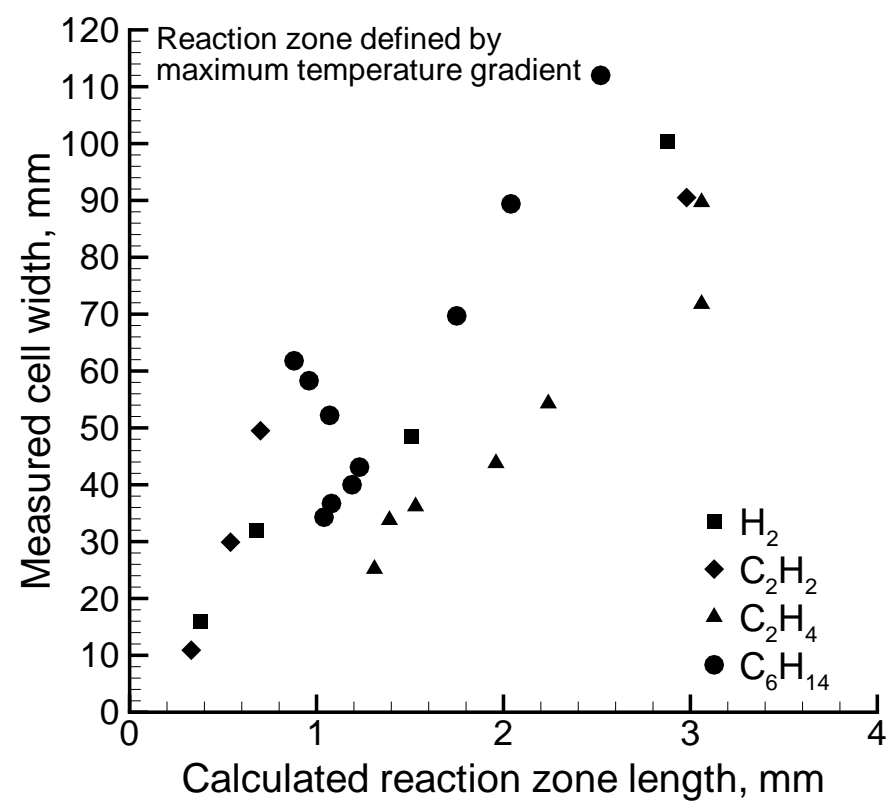

(a)

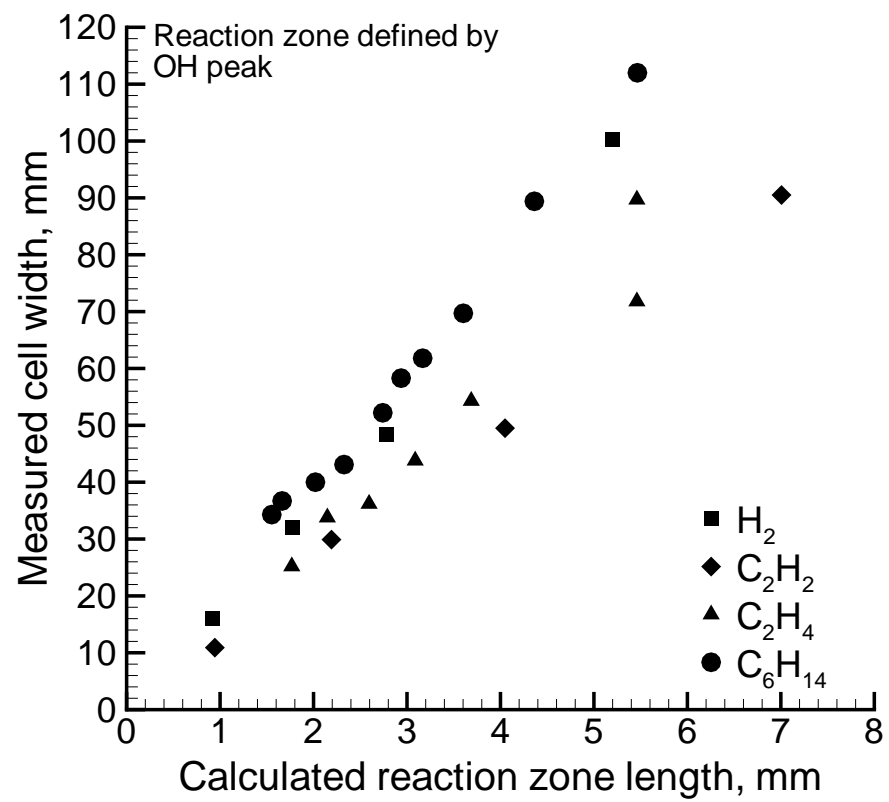

(b)

Figure 26: 